\section{Soil C:N stoichiometry controls carbon sink partitioning between above-ground tree biomass and soil organic matter in high fertility forests}

\author{
Giorgio Alberti ${ }^{(1-7)}$, Sara Vicca ${ }^{(2)}$, Ilaria Inglima ${ }^{(3)}$, Luca \\ Belelli-Marchesini $^{(4-5)}$, Lorenzo Genesio ${ }^{(6)}$, Franco Miglietta ${ }^{(6-7)}$, \\ Hrvoje Marjanovic $^{(8)}$, Cristina Martinez ${ }^{(6-9)}$, Giorgio Matteucci ${ }^{(10-11)}$, \\ Ettore D’Andrea ${ }^{(11)}$, Alessandro Peressotti ${ }^{(1)}$, Fabio Petrella ${ }^{(12)}$, \\ Mirco Rodeghiero ${ }^{(13)}$, Maria Francesca Cotrufo ${ }^{(14)}$
}

The release of organic compounds from roots is a key process influencing soil carbon (C) dynamics and nutrient availability in terrestrial ecosystems. Through this process, plants stimulate microbial activity and soil organic matter (SOM) mineralization thus releasing nitrogen $(\mathrm{N})$ that sustains gross and net primary production (GPP and NPP, respectively). Root inputs also contribute to SOM formation. In this study, we quantified the annual net root-derived $C$ input to soil (Net- $\mathrm{C}_{\text {root }}$ ) across six high fertility forests using an in-growth core isotope technique. On the basis of Net- $C_{\text {root }}$, wood and coarse root biomass changes, and eddy covariance data, we quantified net belowground $C$ sequestration. Belowground $\mathrm{C}$ accumulation and GPP were inversely related to soil C:N, but not to climate or stand age. Soil $\mathrm{C}$ content and $\mathrm{C}: \mathrm{N}$ were also related to soil texture. At these high fertility sites, biomass growth did not change with soil C:N; however, biomass growth-to-GPP ratio significantly increased with increasing soil $\mathrm{C}: \mathrm{N}$. This was true for both our six forest sites and for another 23 high fertility sites selected at a global scale. We suggest that, at high fertility sites, plant $\mathrm{N}$ demand interacts with soil $\mathrm{C}: \mathrm{N}$ stoichiometry and microbial activity, resulting in higher allocation of $\mathrm{C}$ to above ground tree biomass with increasing soil $C: N$ ratio. When $C: N$ is high, microbes have a low $C$ use efficiency, respire more of the fresh $C$ inputs by roots and prime SOM decomposition, thereby increasing $\mathrm{N}$ availability for tree uptake. Soil $\mathrm{C}$ sequestration would therefore decrease, whereas the extra $\mathrm{N}$ released during SOM decomposition can promote tree growth and ecosystem $\mathrm{C}$ sink allocation in aboveground biomass. Conversely, $\mathrm{C}$ is sequestered in soil when low soil $\mathrm{C}: \mathrm{N}$ promotes $\mathrm{mi}-$ crobial $C$ use efficiency and new SOM formation and stabilization on clay particles.

Keywords: Net Root-derived Carbon, Ingrowth Cores, Soil C:N, Carbon Sequestration, Carbon Partitioning, Isotopes

\section{Introduction}

Forest ecosystems worldwide are currently acting as carbon (C) sinks (Pan et al. 2011). Several factors may, however, influence the magnitude and direction of the net $\mathrm{C}$ balance, including recovery from historical land use (e.g., abandoned agricultural land reverting to forested land), increases in atmospheric $\mathrm{CO}_{2}$ concentration and nitrogen $(\mathrm{N})$ deposition, and climate change (Schimel et al. 2001, Thomas et al. 2010). Nonetheless, while much research has been done to understand the controls on net ecosystem $\mathrm{C}$ balance (Valentini et al. 2000, Rustad et al. 2001, Reichstein et al. 2007a), we know little about the controls on $\mathrm{C}$ sink partitioning between plant biomass and soil organic matter (SOM) pools. Soils may store $\mathrm{C}$ for long periods of time (Lal 2005), accumulating on average three times the $\mathrm{C}$ in terrestrial vegetation (Post et al. 1982). On the other hand, more $\mathrm{N}$ is required per unit of $\mathrm{C}$ stored in soil as compared to plant biomass (Yang \& Luo 2011). Hence, while an allocation to SOM may increase $\mathrm{C}$ sequestration in the long term, a preferential allocation to plant biomass is a more nutrient-efficient $\mathrm{C}$ sequestration process in the shorter term.

Studying ecosystem $\mathrm{C}$ sink partitioning is challenging due to the difficulties associated with quantifying the different ecosystem fluxes. Especially complex is the assessment of rapid and small changes in SOM which are linked to the balance between microbial respiration and plant inputs, including both litter and root-derived C (Schrumpf et al.
(1) Department of Agriculture and Environmental Sciences, University of Udine, Udine (Italy); (2) Research Group of Plant and Vegetation Ecology, Department of Biology, University of Antwerp, Universiteitsplein 1, B-2610 Wilrijk (Belgium); (3) Department of Environmental Science, Second University of Naples, Caserta (Italy); (4) Department for Innovation in Biological, Agro-food and Forest systems, University of Tuscia, Viterbo (Italy); (5) Earth and Climate Cluster, Department of Earth Sciences, VU University Amsterdam (The Netherlands); (6) Institute of Biometeorology, National Research Council of Italy - CNR/IBIMET, Firenze (Italy); (7) MOUNTFOR Project Centre, European Forest Institute, Research and Innovation Centre, Fondazione Edmund Mach (FEM), v. E. Mach 1, I-38010 San Michele all'Adige, TN (Italy); (8) Croatian Forest Research Institute, Jastrebarsko (Croatia); (9) Foxlab Joint CNR-FEM Initiative, v. E. Mach 1, I-38010 San Michele all'Adige, TN (Italy); (10) Institute for Agriculture and Forestry System in the Mediterranean, National Research Council of Italy - CNR/ISAFOM, Rende, CS (Italy); (11) Institute of Agroenvironmental and Forest Biology, National Research Council of Italy CNR/IBAF, Monterotondo, RM (Italy); (12) Istituto per le Piante da Legno e l'Ambiente - IPLA, Turin (Italy); (13) Department of Sustainable Agro-ecosystems and Bioresources, Research and Innovation Centre, Fondazione Edmund Mach (FEM), v. E. Mach 1, I-38010 San Michele all'Adige (Italy); (14) Department of Soil and Crop Science, Colorado State University, Fort Collins, Colorado (USA)

@ Giorgio Alberti (giorgio.alberti@uniud.it) Received: Dec 06, 2013 - Accepted: Jul 13, 2014

Citation: Alberti G, Vicca S, Inglima I, Belelli-Marchesini L, Genesio L, Miglietta F, Marjanovic H, Martinez C, Matteucci G, D'Andrea E, Peressotti A, Petrella F, Rodeghiero M, Cotrufo MF, 2015. Soil C:N stoichiometry controls carbon sink partitioning between above-ground tree biomass and soil organic matter in high fertility forests. iForest 8: 195-206 [online 2014-08-26] URL: http://www.sisef.it/ iforest/contents/?id=ifor1196-008

Communicated by: Giustino Tonon

2011). Thus, belowground $\mathrm{C}$ allocation and subsequent $\mathrm{C}$ dynamics are still far from being accurately quantified and understood (Phillips et al. 2011, Vicca et al. 2012). Root C inputs have been shown to influence soil 
$\mathrm{C}$ sequestration, but both the magnitude and direction of this root effect are variable (Karlen \& Cambardella 1996, Parton et al. 1996, Cardon et al. 2001, Rasse et al. 2005, Dijkstra \& Cheng 2007).

A robust definition of net ecosystem production (NEP) should be based on a full ecosystem mass balance (Randerson et al. 2002), which accounts for both plant and soil sinks. When it is flux-based, NEP is defined as the difference between ecosystemlevel gross photosynthetic gain of $\mathrm{C}$ (gross primary production, $G P P$ ) and ecosystem respiratory losses $\left(R_{\text {eco }}\right)$. Alternatively, $N E P$ $\left(\mathrm{g} \mathrm{C} \mathrm{m}^{-2} \mathrm{y}^{-1}\right)$ can be expressed as (Campbell et al. 2004 - eqn. 1):

$$
N E P=\Delta C_{\text {biomass }}+\Delta C_{\text {soil }}
$$

In deciduous forest ecosystems, $\Delta C_{\text {biomass }}$ is the annual change in plant biomass (wood branches, coarse roots), and $\Delta C_{\text {soil }}$ is the annual net change in soil organic $\mathrm{C}$ (SOC) stock. In this equation, litterfall and fine root turnover are considered as soil $\mathrm{C}$ input and therefore contributing to the $\Delta C_{\text {soil }}$ (see eqn. 2).

Net ecosystem productivity can be directly determined using eddy covariance techniques starting from net ecosystem exchange $(N E E=-N E P$ - Baldocchi 2003, Aubinet et al. 2012). Plant biomass changes are usually estimated via a combination of repeated inventories and allometric relationships (Clark et al. 2001). On the other hand, direct SOC determination methods are generally unable to quantify $\Delta C_{\text {soil }}$ in the short term (Schrumpf et al. 2011), and, at annual timescales, alternative methods are required to estimate soil $\mathrm{C}$ changes.

Considering that the dissolved organic $\mathrm{C}$ (DOC) is typically negligible, representing around $1 \%$ of forest $N P P$ (Luyssaert et al $2010), \Delta C_{\text {soil }}$ can also be written as (eqn. 2 ):

$$
\begin{gathered}
\Delta C_{\text {soil }}=\text { Input }_{\text {soil }}-\text { Output }_{\text {soil }} \\
=\text { Input }_{\text {litter }}+\text { Input }_{\text {root }}-R_{C-\text { rizosphere }}-R h
\end{gathered}
$$

where Input $t_{\text {litter }}$ is the above-ground litterfall (i.e., leaves, branches, wood, etc.), Input $t_{\text {root }}$ is the root-derived $\mathrm{C}$ input (i.e., exudates, root slashing and turnover), $R_{\mathrm{C} \text {-rhizosphere }}$ is the rhizosphere respiration of root-derived $\mathrm{C}$, and $R h$ is the heterotrophic respiration. Litter input is conventionally measured by litter traps, while wood input is measured using repeated sampling (Harmon \& Sexton 1996), and rhizosphere and heterotrophic respiration can be estimated by a variety of methods (e.g., trenching, girdling, isotopes), as reviewed by Subke et al. (2006) and Kuzyakov (2006). The largest challenge is estimating gross root inputs. However, methods exist to estimate net annual root-derived $\mathrm{C}$ input $\left(\right.$ Net- $\left.C_{\text {root }}\right)$, which is the difference between Input $_{\text {roots }}$ and $R_{\text {C-rhizosphere }}$ (eqn. 3):

$$
\text { Net } C_{\text {root }}=\text { Input }_{\text {roots }}-R_{C-\text { rhizosphere }}
$$

Different tracer methods have been used to date to estimate $\mathrm{Net}-\mathrm{C}_{\text {root}}$, such as pulse labeling, continuous labeling, and ${ }^{13} \mathrm{C}$ natural abundance (Kuzyakov \& Domanski 2000). The latter uses the difference in the stable C isotope composition of native $\mathrm{SOM}$ and new plant-derived organic matter to quantify Net$C_{\text {root. }}$. When natural isotope abundances do not allow the use of this approach, distinct $\mathrm{C}$ isotope signatures in the soil organic $\mathrm{C}$ (SOC) pool and plant-derived organic matter can be obtained in manipulation experiments, by growing $\mathrm{C}_{3}$ plants $\left(\delta^{13} \mathrm{C}\right.$ of approximately $-27 \%$ ) in soil with organic matter derived from $\mathrm{C}_{4}$ plants $\left(\delta^{13} \mathrm{C}\right.$ of approximately $-12 \%$ ) or vice versa. This approach has been successfully applied in pot (Ineson et al. 1995, Vicca et al. 2010) and field studies (Hoosbeek et al. 2004, Cotrufo et al. 2011) and was used in this investigation.

$N e t-C_{\text {root, }}$ combined with aboveground inputs to the soil (litter and dead wood), also provides interesting information about soil $\mathrm{C}$ dynamics. For soils at steady-state $\left(\Delta C_{\text {soil }}=0\right)$, the sum of Net- $C_{\text {root }}$ and aboveground inputs is the amount of $\mathrm{C}$ that replaces SOC decomposition, thus becoming a measure for SOC turnover. For soils which are net $\mathrm{C}$ sinks $\left(\Delta C_{\text {soil }}>0\right)$, this sum exceeds SOC mineralization and a fraction of it enlarges the SOC pool, thus leading to soil $\mathrm{C}$ sequestration. In this context, for soils which are net $\mathrm{C}$ sinks, the ratio between $\Delta C_{\text {soil }}$ and $N e t-C_{\text {root }}+$ aboveground inputs indicates the fate of $\mathrm{C}$ input: the higher the ratio, the larger the contribution of fresh $\mathrm{C}$ to soil $\mathrm{C}$ sequestration. The opposite is true for soils that are net $\mathrm{C}$ sources $\left(\Delta C_{\text {soil }}<0\right)$.

Root $\mathrm{C}$ input rates vary considerably depending on tree species, mychorrhizal associations and environmental factors (Lynch \& Whipps 1990), with values of up to $40 \%$ of net assimilated $\mathrm{C}$ being reported (Van Veen et al. 1991). According to the microbial efficiency-mineral stabilization (MEMS) framework (Cotrufo et al. 2013), the fraction of Net- $C_{\text {root }}$ inputs sequestered in the soil depends on the efficiency of decomposers to convert $\mathrm{C}$ into bio-products as compared to tha amount of $\mathrm{C}$ lost as $\mathrm{CO}_{2}$ (Six et al. 2006) and on soil matrix interactions (Sollins et al. 1996, Kleber et al. 2007). Soil organic matter mineralization is driven by both substrate stoichiometry and microbial demand for resources (Melillo et al. 1982, Hessen et al. 2004): when $\mathrm{N}$ is limiting, microbes use labile substrate to mineralize recalcitrant SOM (Moorhead \& Sinsabaugh 2006, Craine et al. 2007). Root exudates can thus prime SOM decomposition (Lohnis 1926, Bingeman et al. 1953, Fontaine et al. 2004). Clearly, rootderived soil $\mathrm{C}$ inputs can either stimulate soil $\mathrm{C}$ sequestration or, conversely, induce pri- ming with consequent losses of stabilized SOM but likely enhancements in $\mathrm{N}$ availability, which in turn can stimulate plant growth. The key factors determining the direction (and magnitude) of this effect are, however, not yet clear. Understanding the fate of root-derived $\mathrm{C}$, and its effects on $\mathrm{N}$ dynamics and ecosystem $\mathrm{C}$ sequestration, is relevant from an ecological perspective and is also an urgent challenge to address, particularly in the context of global changes such as atmospheric $\mathrm{CO}_{2}$ increase and $\mathrm{N}$ deposition.

The aims of the present study were: (1) to obtain an estimate of Net- Crot $_{\text {rot }}$ six different forest ecosystems; (2) to partition NEP into aboveground tree biomass production and soil C sinks; and (3) to investigate the controls of this partitioning. Specifically, we tested the hypothesis that soil $\mathrm{C}: \mathrm{N}$ stoichiometry controls ecosystem $\mathrm{C}$ uptake $(G P P)$ and sink partitioning (ANPP vs. soil $\mathrm{C})$ across forest ecosystems. To verify if our hypothesis could be generalized to other forests, we tested it on several world forest sites for which $A N P P, G P P$ and soil $\mathrm{C}: \mathrm{N}$ data were available in the literature.

\section{Materials and methods}

\section{Study sites}

Six forests were considered in the present study. Three sites were in central Italy, two sites in northern Italy, and one in Croatia. All sites were equipped with an eddy covariance tower for mass, momentum and energy ecosystem exchange measurements and can be classified as high fertility sites, according to key soil properties (Vicca et al. 2012 - see also Appendix 1). Site characteristics and flux data are reported in Tab. 1, while a brief description for each site is given below.

Roccarespampani $\left(42^{\circ} 24^{\prime} \mathrm{N}, 11^{\circ} 55^{\prime} \mathrm{E}\right.$ Claus \& George 2005, Tedeschi et al. 2006) is a Turkey oak (Quercus cerris L.) coppice forest at about $235 \mathrm{~m}$ a.s.l. in central Italy. Mean annual temperature is $14{ }^{\circ} \mathrm{C}$ and mean annual rainfall is $755 \mathrm{~mm}$. Soil is sandy clay Luvisol (which is typically nutrient rich), derived from sedimentary material of volcanic origin and marine deposits, and is moderately acid $(\mathrm{pH}=5.7)$, with a total depth $>100$ cm (Rey et al. 2002). Cation exchange capacity (CEC) is high, ranging between 19 and 42 meq $100 \mathrm{~g}^{-1}$ in the different soil layers (Tedeschi et al. 2006). The forest has been managed as a "coppice with standards" over the last 200 years, with a rotation cycle varying between 15 and 20 years. Two stands were selected: a 6-year-old coppice (RO1) and a 15-year-old coppice (RO2).

Lecceto (LE - $43^{\circ} 18^{\prime} \mathrm{N}, 11^{\circ} 16^{\prime} \mathrm{E}$ ) is a Holm oak (Quercus ilex L.) coppice with a rotation period of 18-20 years at about 300 $\mathrm{m}$ a.s.l. in central Italy. Holm oak represents 
Tab. 1 - General characteristics for the six forest sites used in this study. $\left(\Delta C_{\text {wood }}\right)$ : change in aboveground wood biomass; $\left(\Delta C_{\text {roots }}\right)$ : change in coarse root biomass; $(N E P)$ : net ecosystem production; $(N E E)$ : net ecosystem exchange; $(G P P)$ : gross primary production; $\left(R_{\text {eco }}\right)$ : ecosystem respiration; (RO1): Roccarespampani site 1; (RO2): Roccarespampani site 2; (LE): Lecceto; (JA): Jastrebarsko; (LM): La Mandria; (CO): = Collelongo. (a): $\mathrm{N}$ wet deposition in 1990 were derived for all sites using published gridded maps with $0.5^{\circ} \times 0.5^{\circ}$ resolution derived from interpolated (krieged) ground data (available at http://www.daac.ornl.gov). Total wet depositions $\left(\mathrm{kg} \mathrm{N}^{-1} \mathrm{y}^{-1}\right)$ were then computed as the sum of aqueous $\mathrm{NO}^{3-}$ and $\mathrm{NH}^{4+}$ fields, which were available. (b): For Collelongo, the reported number refers to direct measurements available for the period 2002-2009 (Flechard et al. 2011).

\begin{tabular}{|c|c|c|c|c|c|c|c|}
\hline Group & Parameters & RO1 & RO2 & $\mathbf{L E}$ & JA & $\mathbf{L M}$ & $\mathrm{CO}$ \\
\hline \multirow{5}{*}{$\begin{array}{l}\text { Vegetation } \\
\text { characteri- } \\
\text { stics }\end{array}$} & Main species & Turkey oak & Turkey oak & Holm oak & Pedunculate oak & $\begin{array}{l}\text { Pedunculate oak } \\
\text { - Hornbeam }\end{array}$ & Beech \\
\hline & Management & $\begin{array}{l}\text { coppice with } \\
\text { standards }\end{array}$ & $\begin{array}{l}\text { coppice with } \\
\text { standards }\end{array}$ & $\begin{array}{l}\text { coppice with } \\
\text { standards }\end{array}$ & high forest & high forest & $\begin{array}{c}\text { coppice con- } \\
\text { verted to high } \\
\text { forest since } 1950\end{array}$ \\
\hline & $\begin{array}{l}\text { Mean stand age in } \\
2006-2007 \text { (years) }\end{array}$ & $\begin{array}{l}6 \text { (approx. } 70 \\
\text { standards ha } \\
\text { of } 20-40 \text { years- } \\
\text { old present) }\end{array}$ & $\begin{array}{l}15 \text { (approx. } 70 \\
\text { standards ha } \\
\text { of } 20-40 \text { years- } \\
\text { old present) }\end{array}$ & 15 & 35 & 80 & 110 \\
\hline & $\begin{array}{l}\text { Aboveground } \\
\text { biomass }\left(\mathrm{kg} \mathrm{C} \mathrm{m}^{-2}\right)\end{array}$ & 1.9 & 4.5 & 5.0 & 6.3 & 7.8 & 13.7 \\
\hline & $\begin{array}{l}\text { Wet } \mathrm{N} \text { deposition } \\
\left(\mathrm{kg} \mathrm{N} \mathrm{ha}^{-1} \mathrm{y}^{-1}\right)^{\mathrm{a}}\end{array}$ & 10.0 & 10.0 & 8.6 & 11.2 & 9.4 & $10.8^{b}$ \\
\hline \multirow[t]{9}{*}{$\begin{array}{l}\text { Soil charac- } \\
\text { teristics }\end{array}$} & Soil type & $\begin{array}{l}\text { Volcanic } \\
\text { Luvisol }\end{array}$ & $\begin{array}{l}\text { Volcanic } \\
\text { Luvisol }\end{array}$ & Xerocrept & $\begin{array}{c}\text { Luvic } \\
\text { Stagnosol }\end{array}$ & $\begin{array}{c}\text { Typic } \\
\text { Fragiudalf }\end{array}$ & $\begin{array}{l}\text { Humic } \\
\text { Alisols }\end{array}$ \\
\hline & $\begin{array}{l}\text { Bulk density } \\
\left(0-15 \mathrm{~cm}, \mathrm{~g} \mathrm{~cm}^{-3}\right)\end{array}$ & 1.29 & 1.29 & 1.20 & 0.77 & 1.09 & 0.58 \\
\hline & $\begin{array}{l}\text { Bulk density } \\
\left(15-30 \mathrm{~cm}, \mathrm{~g} \mathrm{~cm}^{-3}\right)\end{array}$ & 1.25 & 1.25 & 1.20 & 1.11 & 1.27 & 0.66 \\
\hline & $\begin{array}{l}\text { Soil C stock 0-30 cm } \\
\left(\mathrm{kg} \mathrm{C} \mathrm{m}^{-2}\right)\end{array}$ & 8.6 & 7.4 & 27.4 & 7.7 & 7.4 & 14.7 \\
\hline & $\begin{array}{l}\text { Soil N stock 0-30 cm } \\
\left(\mathrm{kg} \mathrm{N} \mathrm{m}^{-2}\right)\end{array}$ & 0.8 & 0.5 & 1.3 & 0.7 & 0.3 & 0.9 \\
\hline & $\mathrm{C}: \mathrm{N}$ & 10 & 14 & 22 & 11 & 24 & 16 \\
\hline & Sand (\%) & 52 & 52 & 40 & 18 & 6 & 6 \\
\hline & Silt (\%) & 12 & 12 & 35 & 28 & 80 & 50 \\
\hline & Clay $(\%)$ & 35 & 35 & 25 & 54 & 14 & 44 \\
\hline \multirow{8}{*}{$\begin{array}{l}\text { Carbon } \\
\text { fluxes }\end{array}$} & $G P P\left(\mathrm{~g} \mathrm{C} \mathrm{m}^{-2} \mathrm{yr}^{-1}\right)$ & 1577 & 1356 & 901 & 1633 & 754 & 1258 \\
\hline & $R \operatorname{eco}\left(\mathrm{g} \mathrm{C} \mathrm{m}^{-2} \mathrm{yr}^{-1}\right)$ & 1060 & 810 & 368 & 1049 & 183 & 722 \\
\hline & $\Delta C_{\text {wood }}\left(\mathrm{g} \mathrm{C} \mathrm{m}^{-2} \mathrm{yr}^{-1}\right)$ & 161 & 315 & 334 & 325 & 360 & 363 \\
\hline & Root:shoot ratio & $\begin{array}{c}0.30 \\
\text { (Mokany et al. } \\
\text { 2006) }\end{array}$ & $\begin{array}{c}0.30 \\
\text { (Mokany et al. } \\
\text { 2006) }\end{array}$ & $\begin{array}{c}0.30 \\
\text { (Mokany et al. } \\
2006)\end{array}$ & $\begin{array}{c}0.30 \\
\text { (Mokany et al. } \\
\text { 2006) }\end{array}$ & $\begin{array}{c}0.30 \\
\text { (Mokany et al. } \\
\text { 2006) }\end{array}$ & $\begin{array}{l}0.28 \\
\text { (assessed at the } \\
\text { site) }\end{array}$ \\
\hline & $\Delta C_{\text {roots }}\left(\mathrm{g} \mathrm{C} \mathrm{m}^{-2} \mathrm{yr}^{-1}\right)$ & 48 & 95 & 100 & 98 & 108 & 102 \\
\hline & $\begin{array}{l}\Delta C_{\text {biomass }}=\Delta C_{\text {wood }}+ \\
\Delta C_{\text {roots }}\left(\mathrm{g} \mathrm{C} \mathrm{m}^{-2} \mathrm{yr}^{-1}\right)\end{array}$ & 209 & 410 & 435 & 423 & 468 & 464 \\
\hline & Litterfall $\left(\mathrm{g} \mathrm{C} \mathrm{m}^{-2} \mathrm{yr}^{-1}\right)$ & 47 & 123 & 107 & 203 & 223 & 245 \\
\hline & $\begin{array}{l}\text { NEP }(=-N E E) \\
\left(\mathrm{g} \mathrm{C} \mathrm{m}^{-2} \mathrm{yr}^{-1}\right)\end{array}$ & 517 & 545 & 533 & 584 & 571 & 535 \\
\hline
\end{tabular}

$81 \%$ of the total tree canopy; others species include Arbutus unedo L., Juniperus communis L., Quercus pubescens L., Phillyrea latifolia L., Fraxinus ornus L. Mean annual temperature is $13.5{ }^{\circ} \mathrm{C}$ and annual average rainfall is $780 \mathrm{~mm}$.

Jastrebarsko (JA - 45 $37^{\prime} \mathrm{N}, 15^{\circ} 41^{\prime} \mathrm{E}$; Marjanovic et al. 2010, 2011) is a 35-yearold forest in Croatia dominated by pedunculate oak (Quercus robur L.) with 19\% of black alder (Alnus glutinosa Haernt.), 14\% hornbeam (Carpinus betulus L.) and 9\% of narrow-leafed ash (Fraxinus angustifolia L.). Mean annual temperature is $10.4{ }^{\circ} \mathrm{C}$ with mean monthly temperatures of $-0.2{ }^{\circ} \mathrm{C}$ and $20.7{ }^{\circ} \mathrm{C}$ in January and July, respectively. Average annual precipitation is 900 $\mathrm{mm}$ year $^{-1}$, of which around $500 \mathrm{~mm}$ falls during the active vegetation period (AprilSeptember). Soil is a Luvic Stagnosol with a depth $>100 \mathrm{~cm}$ and an acidic $\mathrm{pH}(4.9)$ in the upper mineral layer $(0-20 \mathrm{~cm})$ that linearly increases to neutral $\mathrm{pH}$ at depths $>100 \mathrm{~cm}$. At the beginning of the growing season, the soil drains and water content soon drops below water holding capacity $(46 \% \mathrm{v} / \mathrm{v})$ allowing enough oxygen supply for root growth and substantially increasing nutrient availa- bility in these soils, where nutrient availability can be constrained by high water levels.

La Mandria (LM - $45^{\circ} 09^{\prime} \mathrm{N}, 7^{\circ} 34^{\prime} \mathrm{E}$ ) is an 80 -year-old pedunculate oak-hornbeam forest (Quercus robur L. and Carpinus betulus L.) in northern Italy. Mean annual temperature at the site is $11.6^{\circ} \mathrm{C}$ and annual precipitation is $1030 \mathrm{~mm}$. Soil is Typic Fragiudalf with adequate moisture content throughout the year, neutral $\mathrm{pH}$ and good CEC (ranging from 17 to $11 \mathrm{meq} 100 \mathrm{~g}^{-1}$ at soil surface and $\mathrm{Bh}$ horizons, respectively).

Collelongo $\left(\mathrm{CO}-41^{\circ} 52^{\prime} \mathrm{N}, 13^{\circ} 38^{\prime} \mathrm{E}\right.$; Valentini et al. 1996, Scartazza et al. 2004) 
is an 110-years-old pure beech (Fagus sylvatica L.) forest in northern Italy that has been part of the network of Long Term Ecological Research sites (LTER Italy) since 2006 Mean annual temperature at the site is $7.1^{\circ} \mathrm{C}$ and mean annual rainfall is $1188 \mathrm{~mm}$. The soil is a Humic Alisol with volcanic ash also present. Both CEC and $\mathrm{N}$ content are high in the different soil layers, ranging from 14.8 to $23.3 \mathrm{meq} 100 \mathrm{~g}^{-1}$ and from 4 to $7.3 \mathrm{mg} \mathrm{N} \mathrm{g}^{-1}$, respectively (Persson et al. 2000). Wet $\mathrm{N}$ deposition rates in the period 2002-2009 averaged $10.8 \mathrm{~kg} \mathrm{~N}^{-1} \mathrm{yr}^{-1}$ (Flechard et al. 2011)

\section{Net root-derived C input to soil}

$\mathrm{Net}-\mathrm{C}_{\text {root }}$ was quantified using the in-growth core isotope technique, following Cotrufo et al. (2011). A soil depleted in ${ }^{13} \mathrm{C}\left(\delta^{13} \mathrm{C}=\right.$ $-17.22 \%$ ) was collected from the USDAARS Central Plains Experimental Range located in NE Colorado, USA $\left(40^{\circ} 49^{\prime} \mathrm{N}, 104^{\circ}\right.$ $\left.46^{\prime} \mathrm{W}\right)$. The soil is classified as a Zigweid soil series (Fine-loamy, mixed, superactive, mesic Ustic Haplocambid), with a $\mathrm{pH}$ of 7.4 $\mathrm{N}$ content of $1.37 \mathrm{~g} \mathrm{~kg}^{-1}$, and $\mathrm{P}$ content of 0.5 $\mathrm{g} \mathrm{kg}^{-1}$ (Cotrufo et al. 2011). At this site, plant cover is approximately $75 \% \mathrm{C}_{4}$ grasses, and for brevity we call henceforth this soil as " $\mathrm{C}_{4}$ soil". Soil was air-dried prior to being sealed and boxed for shipment to Italy. Upon arrival, the $\mathrm{C}_{4}$ soil was ground and sieved to 2 $\mathrm{mm}$ and well mixed to make a homogeneous soil pool, before using it for in-growth cores and chemical $\left(\mathrm{C} \%\right.$ and $\left.\delta^{13} \mathrm{C}\right)$ analyses as described below.

At each forest site, six cores, made of a 2 $\mathrm{mm}$ mesh net (thus allowing the penetration of fine roots) with a diameter of $4 \mathrm{~cm}$ and a height of $30 \mathrm{~cm}$, were placed randomly within the eddy covariance tower footprint in October 2006 (2008 for Jastrebarsko) and filled with the $\mathrm{C}_{4}$ soil to a bulk density similar to the average bulk density for the site. At the top of each core the net was closed to avoid above-ground litter input. Cores were sampled a year later, and the soil from each core was separated into $0-15 \mathrm{~cm}$ and $15-30 \mathrm{~cm}$ depth layers, except for Jastrebarsko, where the entire $0-30 \mathrm{~cm}$ core was considered.

All soil samples were sieved to $2 \mathrm{~mm}$, and root samples carefully removed and washed with deionized water. Root samples were pooled by site and depth, and each samples analyzed in triplicates. Both soil and root samples were oven-dried at $70{ }^{\circ} \mathrm{C}$, pulverized and analyzed for $\% \mathrm{C}$ and $\delta^{13} \mathrm{C}$ by an elemental analyzer (Flash EA $1112 \mathrm{NC}, \mathrm{CE}$ Instrument, Wingan, UK) connected to an Isotope Ratio Mass Spectrometer (IRMS, Delta Plus, Thermo-Finnigan, Bremen, Germany). Prior to $\mathrm{C}$ analyses, soil samples were treated with $\mathrm{HCl}$ to eliminate carbonates (Harris et al. 2001). The measured $\delta^{13} \mathrm{C}$ values were used to calculate the proportion of new $\mathrm{C}$ $\left(f_{\text {new }}\right.$, i.e., the $\left.N e t-C_{\text {root }}\right)$, by using a mass ba- lance equation (Del Galdo et al. 2003, Cotrufo et al. 2011 - eqn. 4):

$$
f_{\text {new }}=\frac{\delta_{\text {soil }}-\delta_{\text {old }}}{\delta_{\text {veg }}-\delta_{\text {old }}}
$$

where $\delta_{\text {soil }}$ is $\delta^{13} \mathrm{C}$ of the organic matter of the $\mathrm{C}_{4}$ soil collected from each core after one year of field incubation, $\delta_{\text {old }}$ is the $\delta^{13} \mathrm{C}$ of the organic matter of the $\mathrm{C}_{4}$ soil measured before incubation, and $\delta_{\text {veg }}$ is the $\delta^{13} \mathrm{C}$ of the roots averaged by site and depth. The average $\delta_{\text {veg }}$ value across all our sites was $-28.11 \pm 0.29 \%$, while variation (standard deviation) within a site was between 0.15 and $0.57 \%$ at RO1 and $\mathrm{RO} 2$, respectively. Knowing the $f$ values for the new $\mathrm{C}$, the soil organic $\mathrm{C}$ concentrations $(\% \mathrm{C})$, soil depth $(\mathrm{D}, \mathrm{m})$, and soil bulk density $\left(\sigma, \mathrm{kg} \mathrm{m}^{-3}\right)$, Net- $C_{\text {root }}$ amounts $\left(\mathrm{g} \mathrm{m}^{-2}\right)$ were computed for all soil samples as follows (eqn. 5):

$$
C=f \cdot \% C \cdot \sigma \cdot D
$$

Estimates of Net- $C_{\text {root }}$ using this method (Cotrufo et al. 2011) rely on the assumptions that: (1) root inputs are the same inside and outside the in-growth bags and are independent of the $\mathrm{C}_{4}$ soil properties; and (2) that there is no isotopic fractionation during the decomposition of the native SOM or formation of the new SOM from the root tissues. New studies applying this method should test those assumptions, since some fractionation could occur (Hobbie et al. 2004).

\section{Ecosystem fluxes and primary} production

Eddy covariance flux data from all five Italian sites were analyzed for the years 20062007 (Tab. 1). Data of net ecosystem exchange (NEE), gross primary production $(G P P)$ and ecosystem respiration $\left(R_{\text {eco }}\right)$ at monthly time steps were downloaded from the central Fluxnet database (http://gaia.agra ria.unitus.it/database/). Specifically, we used the NEE gap-filled data using the Artificial Neural Network method (NEE_ANN from level 4 dataset - Papale et al. 2006). $R_{\text {eco }}$ was computed according to the short-term temperature response of night-time fluxes (Reichstein et al. 2005) and GPP values were derived as sum of the absolute values of NEE_ANN and $R_{\text {eco. }}$. At sites where data for the years 2006 or 2007 were incomplete even after gap-filling because of missing weather data, data for 2008 were also included in the analysis for the calculation of annual means. As for the Jastrebarsko site, 2009 eddy flux data were derived from Marjanovic et al. (2010).

Mean annual temperature (MAT), mean annual precipitation (MAP), and soil C stocks $(0-30 \mathrm{~cm})$, as well as changes in wood biomass (stem and branches $-\Delta C_{\text {wood }}$ ), were derived from ancillary data files available at the central database, updated to 2006-2007 when necessary, or using specific yield tables available at the site (e.g., Jastrebarsko). All data were checked, if necessary updated and completed by site Principal Investigators, who are co-authors of the present study. Changes in root biomass $\left(\Delta C_{\text {roots }}\right)$ were derived from $\Delta C_{\text {wood }}$ using root-to-shoot ratios reported by Mokany et al. (2006) or using site-specific relationships as in the case of Collelongo and do not include fine root productivity.

$A N P P$ was calculated as the sum between $\triangle C_{\text {biomass }}$ and $N P P_{\text {leaves }}$ (foliar net primary production). The latter corresponds to litterfall in the case of broadleaved forests, and was directly measured at the site (i.e., Rocca, Jastrebarsko, Collelongo) or assessed from $N P P_{\text {wood }}$ using biomass expansion factors derived at nearby sites with similar species composition and structure (i.e., La Mandria). In the case of Lecceto, where the dominant species is evergreen (Holm oak), we assumed that the system was at steady state and thus litterfall $=N P P_{\text {leaves }}$. Then the $A N P P$ : $G P P$ ratio was calculated.

\section{World forest sites data}

In order to test if the relationship between $A N P P: G P P$ and soil $\mathrm{C}: \mathrm{N}$, observed across our study sites, was generalizable across forest ecosystems, we searched published datasets (Litton et al. 2007, Luyssaert et al. 2007, Vicca et al. 2012) for forest sites that provided the data suitable to our analyses. Twenty-three additional sites were found including $A N P P$ and GPP data, as well as soil C:N (determined for a depth up to $45 \mathrm{~cm}$ ) were found (Tab. 2). Fertility classification followed Vicca et al. (2012). More details are given in Appendix 1.

\section{Data analysis}

At each site the annual change in net soil $\mathrm{C}$ $\left(\Delta C_{\text {soil }}-\mathrm{g} \mathrm{C} \mathrm{m}^{-2} \mathrm{y}^{-1}\right)$ was calculated starting from eddy covariance $N E E$ data and measured changes in aboveground wood biomass $\left(\Delta C_{\text {wood }}\right)$ and coarse roots $\left(\Delta C_{\text {roots }}\right)$ by re-arranging eqn. 1 (eqn. 6):

$$
\begin{aligned}
\Delta C_{\text {soil }}= & -N E E-\Delta C_{\text {wood }}-\Delta C_{\text {roots }} \\
& =N E P-\Delta C_{\text {biomass }}
\end{aligned}
$$

Statistical analyses were performed using the package Sigma Plot ${ }^{\circledR} 11.0$ (Systat ${ }^{\circledR}$ Software, San José, CA, USA). Data were tested for normal distributions, using the Shapiro-Wilk's test, and homogeneity of variance, and log transformed when necessary. To assess differences in Net- $C_{\text {root }}$ among sites, a one way analysis of variance (one-way ANOVA) was used. Significant treatment (site) effects $(\mathrm{P}<0.05)$ were further explored via a treatment (site) comparison using the Least-Squares means test with Tukey's adjustment for multiple comparisons. For sites 
where data for $0-15$ and $15-30 \mathrm{~cm}$ depths were available, a two-way ANOVA with site and depth as fixed factors was also performed.

A correlation analysis between all available variables was performed using the Spearman's rank method through a correlation matrix in Stata $10 \AA$ (StataCorp ${ }^{\circledR}$, College Station, TX, USA). For variables that were correlated with $\mathrm{p}<0.10$, linear models were fitted to measured data.

\section{Results}

Net root-derived C input to soil

Total Net- $C_{\text {root }}$ in the top $30 \mathrm{~cm}$ soil layer ranged between $420 \mathrm{~g} \mathrm{C} \mathrm{m}^{-2}$ year $^{-1}$ at Collelongo and $818 \mathrm{~g} \mathrm{C} \mathrm{m}^{-2}$ year $^{-1}$ at Jastrebarko (Fig. 1). Mean annual Net- $C_{\text {root }}$ across sites was $606 \pm 164 \mathrm{~g} \mathrm{C} \mathrm{m}^{-2}$ year $^{-1}$ (mean \pm stan- dard deviation). A significant difference in total $N e t-C_{\text {root }}(0-30 \mathrm{~cm})$ was detected among sites (ANOVA, $\mathrm{p}=0.007$ ). In particular, post-hoc Tukey's tests showed a significant difference between Jastrebarsko and Collelongo $(p=0.013)$ and Lecceto and Collelongo $(p=0.041-$ Fig. 1$)$. For sites where data for $0-15$ and $15-30 \mathrm{~cm}$ depths were available (i.e., all sites except Jastrebarsko), the two-way ANOVA applied showed significant differences among sites $(p=0.004)$, between depths $(p=0.024)$ and for site $\times$ depth interaction $(p=0.035)$. No differences among sites were detected at $0-15 \mathrm{~cm}$ depth (Tukey's test: $\mathrm{p}>0.05$ ), while $N e t-C_{\text {root }}$ at $15-30 \mathrm{~cm}$ in Lecceto was significantly different from Rocca1 $(\mathrm{p}=0.002)$, Collelongo $(\mathrm{p}$ $=0.003)$ and Rocca2 $(\mathrm{p}=0.021)$. Climate (i.e., MAT, MAP, soil water content) did not explain significant variability in $\mathrm{Net}-\mathrm{C}_{\text {root }}$ among the different sites (see Tab. S1 in Appendix 1). Moreover, total Net- $C_{\text {root }}$ was not significantly correlated to soil $\mathrm{C}: \mathrm{N}$.

\section{Ecoystem C sink partitioning}

All six sites were net $C$ sinks with similar $N E P$ values (average NEP was $547 \pm 25 \mathrm{~g} \mathrm{C}$ $\mathrm{m}^{-2}$ year $\left.{ }^{-1}\right)$ but with large differences in annual GPP (Tab. 1). They actively sequestered $\mathrm{C}$ both aboveground and in the soil: $\triangle C_{\text {wood }}$ represented between 10 and $48 \%$ of annual GPP (RO1 and LM, respectively), $A N P P\left(=\Delta C_{\text {wood }}+\right.$ litterfall $)$ was between 13 and $77 \%$ (RO1 and LM, respectively) and $\Delta C_{\text {soil }}$ was positive for all sites representing between 6 and $20 \%$ of annual GPP (CO and RO1, respectively).

In accordance with our hypothesis, GPP and $\Delta C_{\text {soil }}$ were correlated to soil $\mathrm{C}: \mathrm{N}(\mathrm{p}=$ 0.0048 and $p=0.07$, respectively - Tab. S1

Tab. 2 - Studies used to validate the relationship between $A N P P: G P P$ and soil C:N across gradients of forest stands and environmental conditions. Nutrient availability was assessed according to Vicca et al. (2012), when possible. (n.a.): not available. (1): Ryan et al. (2004), Binkley et al. (2004); (2) Gholz et al. (1986), Gholz \& Fisher (1982), Gholz et al. (1985); (3) Gower et al. (1997), Ryan et al. (1997), Online BOREAS dataset. Site: "NSA-OJP-9OJP1"; (4): Malhi et al. (1999), Marland et al. (2004); (5) Malhi et al. (1999), Luizao et al. (2004); (6): Chambers et al. (2004), Luizao et al. (2004); (7) Harris et al. (1975), Marland et al. (2004); (8): Kinerson et al. (1977); (9): Woodwell \& Botkin (1970); $A N P P=N P P / 1.3$; Marland et al. (2004); (10): Kutsch et al. (2001); (11) Dilly et al. (2000); (12): Sun et al. (2004); (13): Malhi et al. (2009); (14): Kelliher et al. (2004); (15) Kelliher et al. (2004); (16): Malhi et al. (2009); (17): Present study; $A N P P=\triangle C_{\text {wood }}+$ litterfall.

\begin{tabular}{|c|c|c|c|c|c|c|c|}
\hline Forest type and location & $\begin{array}{l}\text { Management or } \\
\text { treatment }\end{array}$ & $\begin{array}{l}\text { Nutrient } \\
\text { availability }\end{array}$ & $A N P P$ & $G P P$ & $\begin{array}{c}A N P P \\
\quad G P P\end{array}$ & $\begin{array}{l}\text { Depth } \\
\text { (cm) }\end{array}$ & $\begin{array}{l}\text { Soil } \\
\text { C:N }\end{array}$ \\
\hline \multirow{4}{*}{$\begin{array}{l}\text { Eucalyptus saligna plantation, } \\
\text { Pepeekeo, } \mathrm{HI}^{1}\end{array}$} & $2 \mathrm{yr}, 1 \mathrm{x} 1 \mathrm{~m}$ & high & 1427 & 5057 & 0.28 & $0-45$ & 16 \\
\hline & $6 \mathrm{yr}, 1 \mathrm{x} 1 \mathrm{~m}$ & high & 480 & 2369 & 0.20 & $0-45$ & 15 \\
\hline & $2 \mathrm{yr}, 3 \times 3 \mathrm{~m}$ & high & 1456 & 4413 & 0.33 & $0-45$ & 16 \\
\hline & $6 \mathrm{yr}, 3 \times 3 \mathrm{~m}$ & high & 828 & 2930 & 0.28 & $0-45$ & 15 \\
\hline $\begin{array}{l}\text { Pinus radiata plantation, Canberra, } \\
\text { Australia }^{1}\end{array}$ & 20 yr C & medium & 599 & 2415 & 0.25 & $0-30$ & 19 \\
\hline $\begin{array}{l}\text { Pinus elliotii plantation, Bradford, } \\
\text { FL }^{2}\end{array}$ & $7-9 \mathrm{yr}$ & low & 199 & 1407 & 0.14 & $0-15$ & 12 \\
\hline Picea mariana, N-BOREAS ${ }^{3}$ & $150 \mathrm{yr}$ & low & 132 & 563 & 0.23 & n.a. & 13 \\
\hline Pinus banksiana, N-BOREAS ${ }^{3}$ & $63 \mathrm{yr}$ & low & 115 & 677 & 0.17 & n.a. & 15 \\
\hline Oak-Hickory, Oak Ridge, $\mathrm{TN}^{4}$ & $55 \mathrm{yr}$ & low & 510 & 1329 & 0.38 & $0-20$ & 16 \\
\hline Tropical forest, Manaus Brazil ${ }^{5}$ & Old growth & low & 870 & 2620 & 0.33 & $0-10$ & 14 \\
\hline Tropical forest, Manaus Brazil $^{6}$ & Old growth terra firme & low & 650 & 2860 & 0.23 & $0-10$ & 12 \\
\hline Liriodendron, Oak Ridge, $\mathrm{TN}^{7}$ & $50 \mathrm{yr}$ & n.a. & 352 & 2162 & 0.16 & $0-20$ & 14 \\
\hline Pinus taeda, Oak Ridge, $\mathrm{TN}^{8}$ & $16 \mathrm{yr}$ & n.a. & 1490 & 4124 & 0.36 & $0-20$ & 15 \\
\hline Pinus-Quercus, Oak Ridge, $\mathrm{TN}^{9}$ & $43 \mathrm{yr}$ & n.a. & 462 & 1280 & 0.36 & $0-20$ & 14 \\
\hline Bornhoved Alder $^{10}$ & Temperate Humid-Broadleaved & low & 589 & 2420 & 0.24 & $0-30$ & 18 \\
\hline Bornhoved Beech $^{11}$ & Temperate Humid-Broadleaved & medium & 601 & 1324 & 0.45 & $0-5$ & 15 \\
\hline Cascade Head $(1)^{12}$ & Temperate Humid-Needle-leaved & high & 569 & 1400 & 0.41 & $0-30$ & 21 \\
\hline Cascade Head $(1 \mathrm{~A})^{12}$ & Temperate Humid-Broadleaved & high & 640 & 1558 & 0.41 & $0-30$ & 20 \\
\hline Caxiuana $^{13}$ & Tropical Humid-Broadleaved & low & 869 & 3630 & 0.24 & $0-30$ & 13 \\
\hline Jacaranda/K34 ${ }^{13}$ & Tropical Humid-Broadleaved & low & 796 & 3040 & 0.26 & $0-30$ & 17 \\
\hline Metolius $^{14}$ & $\begin{array}{l}\text { Temperate Semi-arid-Needle- } \\
\text { leaved }\end{array}$ & medium & 183 & 1143 & 0.16 & $0-30$ & 20 \\
\hline Metolius young $^{15}$ & $\begin{array}{l}\text { Temperate Semi-arid-Needle- } \\
\text { leaved }\end{array}$ & medium & 104 & 724 & 0.14 & $0-30$ & 21 \\
\hline Tapajos $67^{16}$ & Tropical Humid-Broadleaved & low & 1400 & 3141 & 0.45 & $0-30$ & 15 \\
\hline Rocca $1^{17}$ & Meditteranian Turkey oak & high & 208 & 1577 & 0.13 & $0-30$ & 10 \\
\hline Rocca $2^{17}$ & Meditteranian Turkey oak & high & 438 & 1356 & 0.32 & $0-30$ & 14 \\
\hline Lecceto $^{17}$ & Meditteranian Holm oak & high & 441 & 901 & 0.49 & $0-30$ & 22 \\
\hline Jastrebarsko $^{17}$ & Meditteranian Pedunculate oak & high & 528 & 1633 & 0.32 & $0-30$ & 11 \\
\hline La Mandria $^{17}$ & $\begin{array}{l}\text { Meditteranian Pedunculate oak - } \\
\text { Hornbeam }\end{array}$ & high & 583 & 754 & 0.77 & $0-30$ & 24 \\
\hline Collelongo $^{17}$ & Meditteranian mountain beech & high & 608 & 1258 & 0.48 & $0-30$ & 16 \\
\hline
\end{tabular}




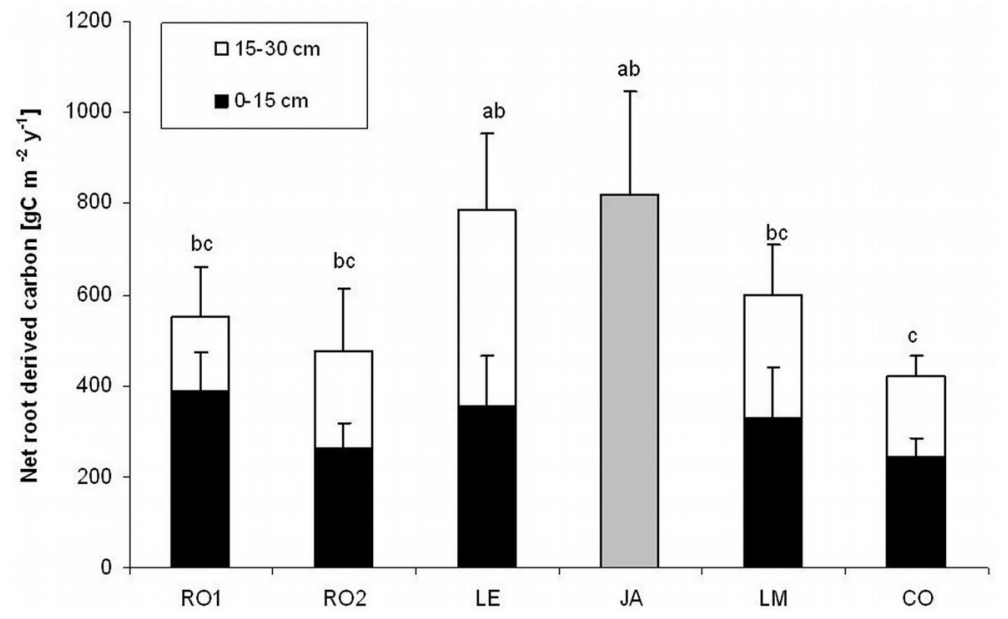

in Appendix 1) and decreased linearly as soil $\mathrm{C}: \mathrm{N}$ increased (Fig. 2). Moreover, GPP was linearly and inversely related to soil clay content $(\mathrm{p}=0.05)$ but, similarly to $\Delta C_{\text {soil }}$, it was not correlated with either MAT, MAP or stand age. $\triangle C_{\text {wood }}$ was weakly related with soil C:N ( $\mathrm{p}=0.07)$, while $\triangle C_{\text {wood }}$ to- $G P P$ ratio (Fig. 3.a) and $A N P P$-to- $G P P$ ratio significantly increased with soil C:N $(\mathrm{p}<0.0001$ and $p=0.005$, respectively - Tab. S1 in Ap-
Fig. 1 - Net annual root-derived carbon input $\left(N e t-C_{\text {root }}\right)$ to soils $(0-15$ and $15-30 \mathrm{~cm})$ quantified using isotope-labelled (e.g., $\mathrm{C}_{4}$ ) soil in-growth cores at the six study sites. Vertical bars indicate standard deviation. Different letters indicate significant difference in total Net- $C_{\text {root }}$ at $p<0.05$. For site labels, see Tab. 1. As for the Jastrebarsko site (JA), only total net derived carbon is reported (grey bar).
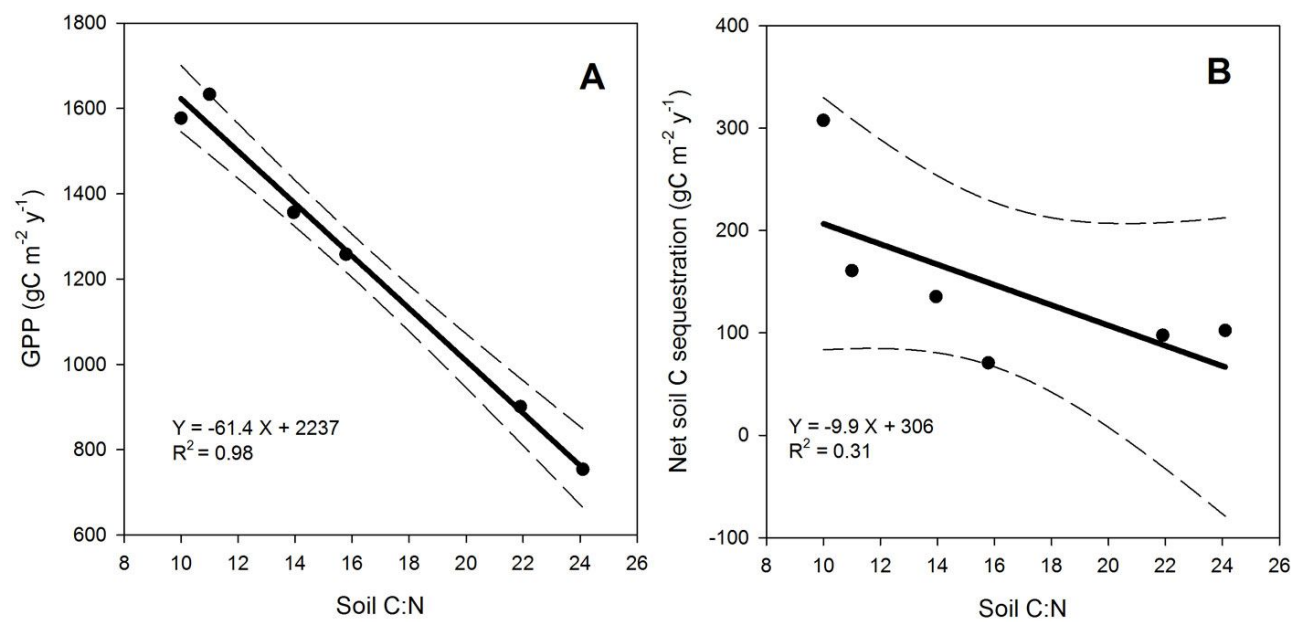

Fig. 2 - Relationships between soil $\mathrm{C}: \mathrm{N}$ stoichiometry and gross primary productivity (GPP - panel A) or net soil $\mathrm{C}$ sequestration (panel $\mathrm{B}$ ) as related to soil $\mathrm{C}: \mathrm{N}$ ratio. Dashed lines represent $95 \%$ confidence interval; the reported $R^{2}$ is the adjusted $R^{2}$.
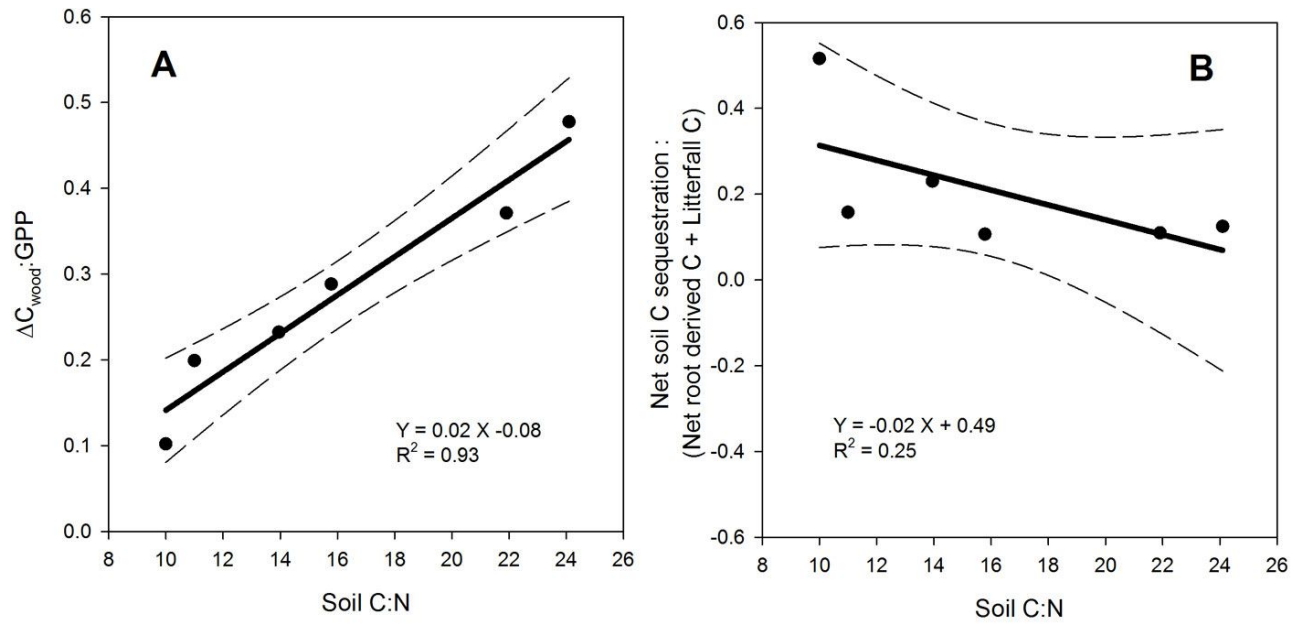

Fig. 3 - Relationships between soil $\mathrm{C}: \mathrm{N}$ stoichiometry and $\Delta C_{\text {wood }}$-to$G P P$ ratio (panel A), or $\Delta C_{\text {soil }}$ : (Net$C_{\text {root }}+$ litterfall) ratio (panel B). Dashed lines represent $95 \%$ confidence interval; the reported $\mathrm{R}^{2}$ is the adjusted $\mathrm{R}^{2}$. 


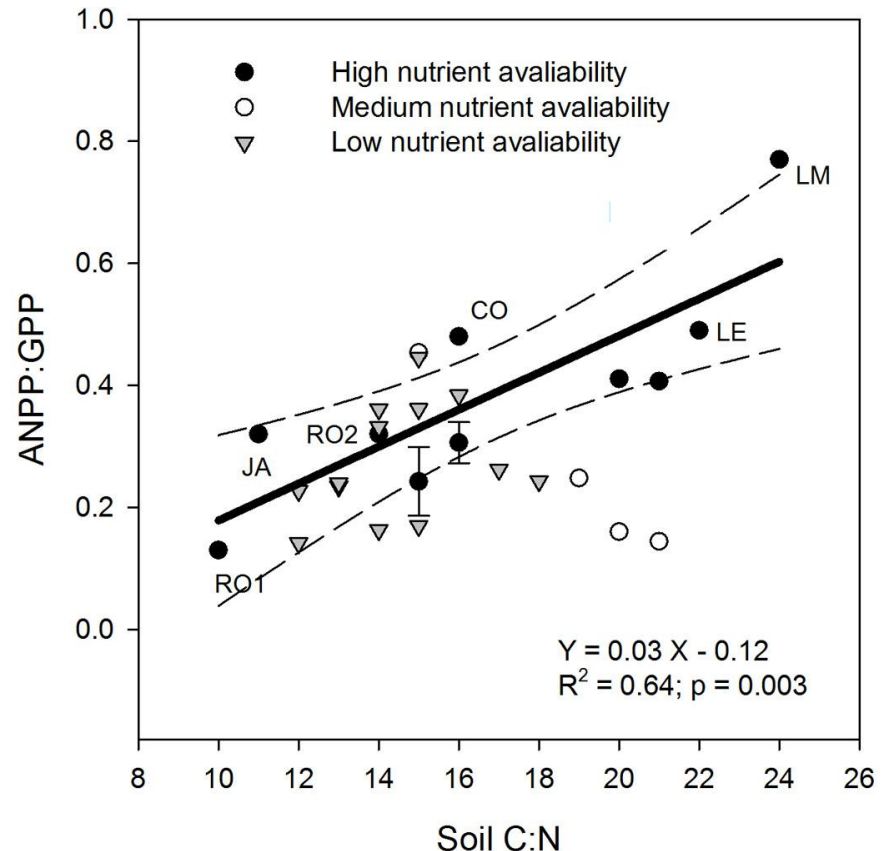

Fig. 4 - Relationships between soil $\mathrm{C}: \mathrm{N}$ stoichiometry and the $A N P P: G P P$ ratio at forest sites with different fertility levels. For the complete list of sites see Tab. 2. Dashed lines represent 95\% confidence intervals. The six sites considered in the present study are labeled as reported in Tab. 1. Eucalyptus saligna plantations (Tab. 2) have been averaged by stand age and vertical bars indicate standard deviation. The reported $\mathrm{R}^{2}$ is the adjusted $\mathrm{R}^{2}$.

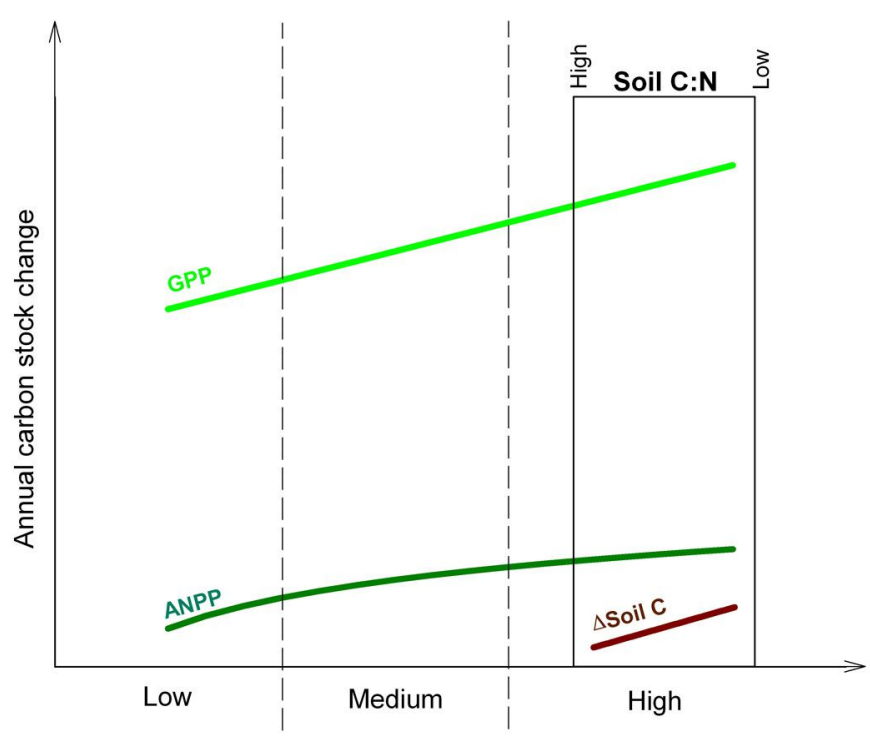

Nutrient avaliability

Fig. 5 - Schematic representation of the proposed dynamics of gross $(G P P)$ and aboveground net primary production $(A N P P)$ with changes in nutrient availability. At high fertility sites (such as the sites considered in the present paper), GPP, ANPP and soil C sequestration $(\triangle C)$ changes are controlled by soil $\mathrm{C}: \mathrm{N}$ stoichiometry. At low soil C:N ratio, $\mathrm{C}$ sink allocation shifts from NPP to soil $\mathrm{C}$ sequestration. cluding additional fertile forests from different regions (Tab. 2). In particular, a positive relationship was found between $A N P P: G P P$ and soil C:N for high fertility (sensu Vicca et al. 2012) sites (adjusted- $\mathrm{R}^{2}=0.64 ; \mathrm{p}=0.03$; Fig. 4). Conversely, no significant relationship was detected for low and medium fertility sites.

\section{Discussion and conclusions}

To our knowledge, this study is the first to quantify Net- $C_{\text {root }}$ in a range of forest ecosystems. The measurement of Net- $C_{\text {root }}$ in situ is difficult, thus measured values are lacking and modeled estimates cannot be validated. However, the in-growth core isotope technique has already been shown to allow detection of changes in Net- $C_{\text {root }}$ in $\mathrm{CO}_{2}$ and climate manipulation experiments (Hoosbeek et al. 2004, Cotrufo et al. 2011), even though it does suffer from several caveats related to the use of an exogenous soil and high spatial variability. Steingrobe et al. (2000) reviewed the in-growth core method for measuring gross root growth: a first shortcoming associated with this method is achieving the soil conditions inside the bag similar to the bulk soil. Moreover, soil texture has also been shown to significantly influence rhizodeposition rates (Scandellari et al. 2010), although it is difficult to determine whether soil texture influenced rhizodeposition rates in our study.
Our estimates of Net-C $C_{\text {root }}$ using the ingrowth core isotope technique were on average $606 \mathrm{~g} \mathrm{C} \mathrm{m}^{-2} \mathrm{y}^{-1}$, which is higher than values reported by Cotrufo et al. (2011) for a Arbutus unedo L. coppice in dry Mediterranean conditions, but lower than values reported by Hoosbeek et al. (2004) for an irrigated and fertilized poplar plantation in central Italy. A possible overestimation of Net$C_{\text {root }}$ can be also related to the fact that a certain amount of fine root fragments could have passed through the $2 \mathrm{~mm}$ sieve. Such an amount is a function of root integrity as affected by plant age and sample processing. Being aware of this possible overestimation and of the above-mentioned limitations associated with the in-growth core isotope technique, in this study we used Net-C $C_{\text {root }}$ estimates solely as an indicator of differences in the effect of root-derived C on SOC sequestration through the calculation of the ratio $\Delta C_{\text {soil }}$ : (Net root-derived $\mathrm{C}+$ litterfall $\mathrm{C}$ ).

Many factors have been suggested to affect soil $\mathrm{C}$ sequestration, including the characteristics of input material, soil texture and mineralogy, climatic factors, and soil nutrient status (Galantini et al. 1992, Andrén \& Kätterer 1997, Janssens et al. 2010). We found that the proportion of root $\mathrm{C}$ input resulting in $\mathrm{C}$ sequestration at these high fertility sites was related to soil $\mathrm{C}: \mathrm{N}$ ratio, and soil $\mathrm{C}$ sequestration was greater at low C:N (Fig. 2b) therefore confirming our hypothesis. Recen- tly, Manzoni et al. (2012) suggested a C-tonutrient stoichiometric control on microbial C use efficiency (CUE), which would increase with increasing nutrient availability. The importance of CUE as a determinant of the fate of plant inputs to soils has also been recognized by other recent studies (Schimel \& Schaeffer 2012, Cotrufo et al. 2013) and some models have suggested that low nutrient availability, particularly $\mathrm{N}$, might limit soil $\mathrm{C}$ storage through mechanisms that are still not completely understood (Rastetter et al. 1997, Hungate et al. 2003). Recently, Kirkby et al. (2013) hypothesized that the sequestration of C-rich crop residue material into SOM could be improved only by adding supplementary nutrients, as the more stable SOM fraction has more $\mathrm{N}, \mathrm{P}$ and $\mathrm{S}$ per unit of $\mathrm{C}$ than the plant material input due to microbial reprocessing. Thus, the increase in soil $\mathrm{C}$ sequestration at lower soil $\mathrm{C}: \mathrm{N}$ values observed in this study may be explained by a higher microbial CUE of root $\mathrm{C}$ inputs.

Soil C:N exerted a strong control on $G P P$ across our six forests and GPP increased with decreasing soil C:N (Fig. 2a). This relationship is based on six forest sites and we cannot exclude the possibility that other factors influenced this relation. At the ecosystem scale, variation in global plant productivity across ecosystems has often been related to environmental factors (Field et al. 1995, Reichstein et al. 2007b), but also to 
nutrient availability (Vicca et al. 2012). In this context, Zha et al. (2013) reported a strong positive relationship between GPP or $N P P$ and total soil N. Across our sites, $\triangle C_{\text {wood }}$ and $A N P P$ increased slightly, but no significantly with increasing soil $\mathrm{C}: \mathrm{N}$, and showed significant relations with MAT, MAP and stand age, thus confirming previous studies (Curtis et al. 2002, Hsu et al. 2012, Robinson et al. 2012, He et al. 2012). How such different behavior between $G P P$ and $\triangle C_{\text {wood }}$ or $A N P P$ with respect to soil C:N could be explained? We suggest that this result is due to the lower demand for $\mathrm{N}$ by woody tissues (which comprise the largest fraction of the tree and are characterized by very high $\mathrm{C}: \mathrm{N}$ ) as compared to green leaves (which control GPP, and have much lower $\mathrm{C}: \mathrm{N}$ than woody tissues). As a result of these variations in both $G P P$ and $A N P P$, the ratio between $A N P P$ and $G P P$ varied substantially among our six forest sites.

Following the distinct patterns of $A N P P$ and $G P P$ versus soil $\mathrm{C}: \mathrm{N}$, the $A N P P$-to- $G P P$ ratio significantly increased with increasing soil C:N (Fig. 2a). At first sight, this seems to contradict the current understanding that partitioning of photosynthates into aboveground biomass increases with increasing nutrient availability across a wide range of forests (Vicca et al. 2012). However, all six forest sites had high nutrient availability but at those sites where soil $\mathrm{N}$ presumably exceeded tree demand for wood growth (i.e. sites with low $\mathrm{C}: \mathrm{N}$ ), root $\mathrm{C}$ inputs were probably responsible for the higher net soi $\mathrm{C}$ sequestration. We speculate that the link between soil $\mathrm{C}: \mathrm{N}$ stoichiometry and microbial activity controls $\mathrm{C}$ sequestration belowground, as well as for the increase in $A N P P$ to- $G P P$ ratio with increasing soil $\mathrm{C}: \mathrm{N}$ across the high fertility forests in our dataset. A soil C:N below 15, CUE is expected to be high, and more of the fresh $\mathrm{C}$ input is used for microbial products, resulting in the net formation of new SOM. Conversely, when $\mathrm{C}: \mathrm{N}$ is high, microbes have a low $\mathrm{C}$ use efficiency and therefore they respire more of the fresh $\mathrm{C}$ inputs and prime SOM decomposition (Fontaine et al. 2004), which increases $\mathrm{N}$ availability and supports a higher allocation of fixed C (GPP) to ANPP. Our observations of increasing $A N P P$-to- $G P P$ ratio, and the tendency for a decrease in soil $\mathrm{C}$ sequestration with increasing soil $\mathrm{C}: \mathrm{N}$ (Fig. $2 \mathrm{~b}$ ), support this hypothesis.

In order to further test this hypothesis, we analyzed a larger dataset. Also in this case, $A N P P$-to- $G P P$ ratios were quite variable (average $A N P P: G P P=0.28$ with $\mathrm{SD}=0.10$; Tab. 2) and our analysis confirmed the relationship between $A N P P$-to-GPP ratio and soil $\mathrm{C}: \mathrm{N}$ at sites with high fertility (Fig. 4). At sites where overall nutrient availability was low, this relationship did not hold. Variation in partitioning of $G P P$ to $A N P P$ at these sites is probably driven by the need for plants to invest in the nutrient acquiring system (i.e., roots and root symbionts - Vicca et al. 2012). When nutrient availability is limited, belowground input by plants may be the dominant control of microbial activity and SOM mineralization (Hamilton \& Frank 2001, Wardle et al. 2004, De Deyin et al. 2008, De Graaff et al. 2010), thereby influencing mineral nutrient availability for plant uptake. Our speculation is also consistent with other recent findings. At the Duke Free Air $\mathrm{CO}_{2}$ Enrichment (FACE) experiment, the increase in the belowground $\mathrm{C}$ flux stimulated microbial activity, accelerated SOM decomposition, and stimulated tree uptake of $\mathrm{N}$ bound to this SOM, sustaining ANPP (Drake et al. 2011, 2013, Phillips et al. 2012). Yin et al. (2013) found that an increase in the release of root exudates into the soil was an important physiological mechanism to sustain growth responses of plants to experimental warming.

At our study sites, soil C:N stoichiometry appeared to be weakly controlled by the soil clay content $(\mathrm{p}=0.15$ - Tab. S1 in Appendix $1)$, decreasing with increasing \%clay in soil. This is consistent with our knowledge of soil primary organo-mineral particles, which describes clay-associated SOM as the fraction with the highest microbial contribution and lowest C:N ratio (Christensen 1992, Grandy $\&$ Neff 2008).

In conclusion, our results suggest that a specific site property, such as soil texture, could drive soil $\mathrm{C}: \mathrm{N}$ stoichiometry which in turn would control ecosystem $\mathrm{C}$ uptake and partitioning within forests of high nutrient availability. While GPP strongly and linearly increased with increasing soil $\mathrm{N}$, aboveground tree biomass demand for $\mathrm{N}$ appeared to saturate, possibly because of the higher $\mathrm{C}: \mathrm{N}$ of wood $v s$. green leaves, and, at high nutrient availability, NPP became limited by other environmental factors. When this occurs, more $\mathrm{C}$ is sequestered by soil (Fig. 5), where the high $\mathrm{N}$ availability promotes $\mathrm{CUE}$ efficiency and new SOM formation.

\section{Acknowledgements}

This work was financially supported by the Italian government through the FIRB project "Carboltaly". We thank all site investigators, their funding agencies, the various regional flux networks (Afriflux, AmeriFlux, AsiaFlux, CarboAfrica, CarboEurope-IP, CarboExtreme, ChinaFlux, Fluxnet-Canada, KoFlux, LBA, NECC, OzFlux, TCOS-Siberia, USCCC), development of measurement and data submission protocols (funded by Office of Science (BER), US Department of Energy), and the Fluxnet project, whose work and support was essential for obtaining the measurements without which the type of integrated analyses conducted in this study would have not been possible. SV is a post- doctoral research associate of the Fund for Scientific Research - Flanders. Collelongo is a research site of the Italian network of Long Term Ecological Research (LTER-Italy).

\section{References}

Andrén O, Kätterer T (1997). ICBM: the introductory carbon balance model for exploration of soil carbon balances. Ecological Applications 7: 1226-1236. - doi: 10.1890/1051-0761(1997)007 [1226:ITICBM]2.0.CO;2

Aubinet M, Vesala T, Papale D (2012). Eddy covariance. A practical guide to measurement and data analysis. Springer, Berlin, Germany, pp. 438. [online] URL: http://books.google.it/books? $\mathrm{id}=8 \mathrm{a} 2 \mathrm{bIJER} 5 \mathrm{ZwC}$

Baldocchi D (2003). Assessing the eddy covariance technique for evaluating carbon dioxide exchange rates of ecosystems' past, present and future. Global Change Biology 9: 479-492. - doi: 10.1046/j.1365-2486.2003.00629.x

Binkley D, Kaye J, Barry M, Ryan MG (2004). First-rotation changes in soil carbon and nitrogen in a eucalyptus plantation in Hawaii. Soil Science Society of America Journal 68: 1713-1719. - doi: 10.2136/sssaj2004.1713

Bingeman CW, Varner JE, Martin WP (1953). The effect of the addition of organic materials on the decomposition of an organic soil. Soil Science Society of America Journal 29: 692-696. doi: 10.2136/sssaj1953.03615995001700010008 $\mathrm{x}$

Campbell JL, Sun OJ, Law BE (2004). Disturbance and net ecosystem production across three climatically distinct forest landscapes. Global Biogeochemical Cycles 18: 1-11. - doi: 10.1029/ 2004GB002236

Cardon ZG, Hungate BA, Cambardella CA, Chapin FS, Field CB, Holland EA, Mooney HA (2001). Contrasting effects of elevated $\mathrm{CO}_{2}$ on old and new soil carbon pools. Soil Biology and Biochemistry 33: 365-373. - doi: 10.1016/S0038 $-0717(00) 00151-6$

Chambers JQ, Tribuzy ES, Toledo LC, Crispim BF, Higuchi N, Santos Jd, Araújo AC, Kruijt B, Nobre AD, Trumbore SE (2004). Respiration from a tropical ecosystem: partitioning of sources and low carbon use efficiency.Ecological Applications 14 (sp4): 72-88. - doi: 10.1890/016012

Christensen BT (1992). Physical fractionation of soil and organic matter in primary particles and density separates. Advances in Soil Science 20: 1-90. - doi: 10.1007/978-1-4612-2930-8_1

Clark DA, Brown A, Kicklighter DW, Chambers JQ, Gower ST, Thomlinson J, Ni J (2001). Measuring net primary production in forests: a synthesis of current concepts and field methods. Ecological Applications 11: 356-370. - doi: 10.1890/1051-0761(2001)011[0356:MNPPIF]2. $0 . \mathrm{CO} ; 2$

Claus A, George E (2005). Effect of stand age on fine-root biomass and biomass distribution in three European forest chronosequences. Canadian Journal of Forest Research 35: 1617-1625. doi: $10.1139 / \mathrm{x} 05-079$ 
Cotrufo MF, Alberti G, Inglima I, Marjanovi H, LeCain D, Zaldei A, Peressotti A, Miglietta F (2011). Decreased summer drought affects plant productivity and soil carbon dynamics in a Mediterranean woodland. Biogeosciences 8: 27292739. - doi: 10.5194/bg-8-2729-2011

Cotrufo MF, Wallenstein MD, Boot C, Denef K, Paul E (2013). The Microbial Efficiency-Matrix Stabilization (MEMS) framework integrates plant litter decomposition with soil organic matter stabilization: do labile plant inputs form stable soil organic matter? Global Change Biology 19 (4): 988-995. - doi: 10.1111/gcb.12113

Craine JM, Morrow C, Fierer N (2007). Microbial nitrogen limitation increases decomposition. Ecology 88: 2105-2113. - doi: 10.1890/06-184 7.1

Curtis PS, Hanson PJ, Bolstad P, Barford C, Randolph JC, Schid HP, Wilson KB (2002). Biometric and eddy-covariance based estimates of annual carbon storage in five eastern North American deciduous forests. Agricultural and Forest Meteorology 113: 3-19. - doi: 10.1016/S0168-19 23(02)00099-0

De Deyin GB, Cornelissen HC, Bardgett RD (2008). Plant functional traits and soil carbon sequestration in contrasting biomes. Ecology Letters 11: 516-531. - doi: 10.1111/j.1461-0248.20 08.01164.x

Del Galdo I, Six J, Peressotti A, Cotrufo MF (2003). Assessing the impact of land-use change on soil $\mathrm{C}$ sequestration in agricultural soils by means of organic matter fractionation and stable C isotopes. Global Change Biology 9 (8): 1204 1213. - doi: 10.1046/j.1365-2486.2003.00657.x

De Graaff MA, Classen AT, Castro HF, Schadt CW (2010). Labile soil carbon inputs mediate the soil microbial community composition and plant residue decomposition rates. New Phytologist 188: 1055-1064. - doi: 10.1111/j.1469-81 37.2010.03427.x

Dilly O, Bachb H-J, Buscot F, Eschenbach C, Kutsch WL, Middelhoff U, Pritsch K, Munch JC (2000). Characteristics and energetic strategies of the rhizosphere in ecosystems of the Bornhöved Lake district. Applied Soil Ecology 15: 201-210. - doi: 10.1016/S0929-1393(00)00096-

Dijkstra FA, Cheng WX (2007). Interactions between soil and tree roots accelerate long-term soil carbon decomposition. Ecology Letters 10: 1046-1053. - doi: 10.1111/j.1461-0248.2007.01 095.x

Drake JE, Gallet-Budynek A, Hofmockel KS, Bernhardt ES, Billings SA, Jackson RB, Johnsen KS, Lichter J, McCarthy HR, McCormack ML, Moore DJP, Oren R, Palmroth S, Phillips RP, Pippen JS, Pritchard SG, Treseder KK, Schlesinger WH, DeLucia EH, Finzi AC (2011). Increases in the flux of carbon belowground stimulate nitrogen uptake and sustain the long-term enhancement of forest productivity under elevated $\mathrm{CO}_{2}$. Ecology Letters 14: 349-357. - doi: 10.1111/j.1461-0248.2011.01593.x

Drake JE, Darby BA, Giasson MA, Kramer MA, Phillips RP, Finzi AC (2013). Stoichiometry constrains microbial response to root exudationinsights from a model and a field experiment in a temperate forest. Biogeosciences 10: 821-838. doi: 10.5194/bg-10-821-2013

Dunn A, Barford CC, Wofsy S, Goulden ML, Daube BC (2007). A long-term record of carbon exchange in a boreal black spruce forest: means, responses to interannual variability and decadal trends. Global Change Biology 13: 577-590. doi: 10.1111/j.1365-2486.2006.01221.x

Field CB, Randerson JT, Malmstrom CM (1995). Global net primary production: combining ecology and remote sensing. Remote Sensing of the Environment 51: 74-88. - doi: 10.1016/00344257(94)00066-V

Flechard CR, Nemitz E, Smith RI, Fowler D, Vermeulen AT, Bleeker A, Erisman JW, Simpson D, Zhang L, Tang YS, Sutton MA (2011). Dry deposition of reactive nitrogen to European ecosystems: a comparison of inferential models across the NitroEurope network. Atmospheric Chemistry and Physics 11 (6): 2703-2728. - doi: 10.51 94/acp-11-2703-2011

Fontaine S, Bardoux G, Abbadie L, Mariotti A (2004). Carbon input to soil may decrease soil carbon content. Ecology Letters 7: 314-320. doi: 10.1111/j.1461-0248.2004.00579.x

Galantini J, Rosell R, Andriulo A, Miglierina A, Iglesias J (1992). Humification and nitrogen mineralization of crop residues in semi-arid Argentina. Science of the Total Environment 117: 263-270. - doi: 10.1016/0048-9697(92)90093-8 Gholz HL, Fisher RF (1982). Organic matter production and distribution in slash pine (Pinus elliottii) plantations. Ecology 63: 1827-1839. doi: 10.2307/1940124

Gholz HL, Fisher RF, Prichett WL (1985). Nutrient dynamics in slash pine plantation ecosystems. Ecology 66: 647-689. - doi: 10.2307/1940 526

Gholz HL, Hendry LC, Cropper WPJ (1986). Organic matter dynamics of fine roots in plantations of slash pine (Pinus elliottii) in north Florida. Canadian Journal of Forest Research 16: 529-538. - doi: 10.1139/x86-093

Gower ST, Vogel JG, Norman JM, Kucharik CJ, Steele SJ, Stow TK (1997). Carbon distribution and aboveground net primary production in aspen, jack pine, and black spruce stands in Saskatchewan and Manitoba, Canada. Journal of Geophysical Research 102: 29029-29041. - doi: 10.1029/97JD02317

Grandy AS, Neff JC (2008). Molecular C dynamics downstream: the biochemical decomposition sequence and its impact on soil organic matter structure and function. Science of the Total Environment 404: 297-307. - doi: 10.1016/j.scitotenv.2007.11.013

Hamilton EW, Frank DA (2001). Can plants stimulate soil microbes and their own nutrient supply? Evidence from a grazing tolerant grass. Ecology 82: 2397-2402. - doi: 10.1890/00129658(2001)082[2397:CPSSMA]2.0.CO;2

Harmon ME, Sexton J (1996). Guidelines for measurements of woody debris in forest ecosystems. US Long Term Ecological Research Net- work Office, University of Washington, Washington, DC, USA, pp. 42. [online] URL: http:// and.1ternet.edu/lter/pubs/pdf/misc/pub2255orig. pdf

Harris WF, Sollins P, Edwards NT, Kinger BE, Shugart HH (1975). Analysis of carbon flow and productivity in a temperate deciduous forest ecosystem. In: "Productivity of World Ecosystems" (Reichle DE, Franklin JF, Goodall DW eds). National Academy of Sciences, Washington, DC, USA, pp. 116-122.

Harris D, Horwath WR, Van Kessel C (2001). Acid fumigation of soils to remove carbonates prior to total organic carbon or Carbon-13 isotopic analysis. Soil Science Society of America Journal 65: 1853-1856. - doi: 10.2136/sssaj200 1.1853

He L, Chen JM, Pan Y, Birdsey R, Kattge J (2012). Relationships between net primary productivity and forest stand age in U. S. forests, Global Biogeochemical Cycles 26 (3): GB3009. - doi: 10.1029/2010GB003942

Hessen DO, Agren GI, Anderson TR, Elser JJ, De PC R (2004). Carbon sequestration in ecosystems: the role of stoichiometry. Ecology 85: 1179-1192. - doi: 10.1890/02-0251

Hobbie EA, Johnson MG, Rygiewicz PT, Tingey DT, Olszyk DM (2004). Isotopic estimates of new carbon inputs into litter and soils in a fouryear climate change experiment with Douglasfir. Plant and Soil 259: 331-343. - doi: 10.1023/ B:PLSO.0000020975.75850.ca

Hoosbeek MR, Lukac M, Van Dam D, Godbold DL, Velthorst EJ, Biondi FA, Peressotti A, Cotrufo MF, De Angelis P, Scarascia-Mugnozza G (2004). More new carbon in the mineral soil of a poplar plantation under Free Air Carbon Enrichment (POPFACE): Cause of increased priming effect? Global Biogeochemical Cycles 18 (1): GB1040. - doi: 10.1029/2003GB002127

Hungate BA, Dukes JS, Shaw MR, Luo Y, Field CB (2003). Nitrogen and climate change. Science 302: 1512-1513. - doi: 10.1126/science. 1091390

Hsu JS, Powell J, Adler PB (2012). Sensitivity of mean annual primary production to precipitation. Global Change Biology 18: 2246-2255. - doi: 10.1111/j.1365-2486.2012.02687.x

Ineson P, Cotrufo MF, Bol R, Harkness DD, Blum $H$ (1995). Quantification of soil carbon inputs under elevated $\mathrm{CO}_{2}$ : C-3 plants in a C-4 soil. Plant Soil 187: 345-350. - doi: 10.1007/BF0001 7099

Karlen DL, Cambardella CA (1996). Conservation strategies for improving soil quality and organic matter storage. In: "Structure and Organic Matter Storage in Agricultural Soils" (Carter R, Stewart BA eds). CRC Press, Boca Raton, FL, USA, pp. 395-420.

Kelliher F, Ross D, Law B, Baldocchi D, Rodda N (2004). Limitations to carbon mineralization in litter and mineral soil of young and old ponderosa pine forests. Forest Ecology and Management 191 (1-3): 201-213. - doi: 10.1016/j.foreco. 2003.12.005

Kinerson RS, Ralston CW, Wells CG (1977). Car- 
bon cycling in a loblolly pine plantation. Oecologia 29: 1-10. - doi: 10.1007/BF00345358

Kirkby CA, Richardson AE, Wade LJ, Batten GD, Blanchard C, Kirkegaard JA (2013). Carbon-nutrient stoichiometry to increase soil carbon sequestration. Soil Biology and Biochemistry 60: 77-86. - doi: 10.1016/j.soilbio.2013.01.011

Kleber M, Sollins P, Sutton R (2007). A conceptual model of organo-mineral interactions in soils: self-assembly of organic molecular fragments into zonal structures on mineral surfaces. Biogeochemistry 85: 9-24. - doi: 10.1007/s105 33-007-9103-5

Kutsch WL, Staack A, Wötzel J, Middelhoff U, Kappen L (2001). Field measurements of root respiration and total soil respiration in an alder forest. New Phytologist 150: 157-168. - doi 10.1046/j.1469-8137.2001.00071.x

Kuzyakov Y, Domanski G (2000). Carbon input by plants into the soil. Review. Journal of Plant Nutrition and Soil Science 163: 421-431. - doi: 10.1002/1522-2624(200008)163:4<421::AIDJPLN421>3.0.CO;2-R

Kuzyakov Y (2006). Sources of $\mathrm{CO}_{2}$ efflux from soil and review of partitioning methods. Soil Biology and Biochemistry 38: 425-448. - doi: 10.1016/j.soilbio.2005.08.020

Janssens IA, Dieleman W, Luyssaert S (2010). Reduction of forest soil respiration in response to nitrogen deposition. Nature Geoscience 3: 315 322. - doi: 10.1038/ngeo844

Lal R (2005). Forest soils and carbon sequestration. Forest Ecology and Management 220: 242258. - doi: 10.1016/j.foreco.2005.08.015

Lynch JM, Whipps JM (1990). Substrate flow in the rhizosphere. Plant Soil 129: 1-10. - doi: 10.1007/BF00011685

Litton CM, Raich JW, Ryan MG (2007). Carbon allocation in forest ecosystems. Global Change Biology 13: 2089-2109. - doi: 10.1111/j.1365-24 86.2007.01420.x

Lohnis F (1926). Nitrogen availability of green manures. Soil Science 22: 253-290. - doi: 10.10 97/00010694-192610000-00001

Luizao RCC, Luizao FJ, Paiva RQ, Monteiro TF, Sousa LS, Kruijt B (2004). Variation of carbon and nitrogen cycling processes along a topographic gradient in a central Amazonian forest. Global Change Biology 10: 592-600. - doi: 10.11 11/j.1529-8817.2003.00757.x

Luyssaert S, Inglima I, Jung M, Richardson AD, Reichstein M, Papale D, Piao SL, Schulze E-, Wingate L, Matteucci G, Aragao L, Aubinet M, Beer C, Bernhofer C, Black KG, Bonal D, Bonnefond J, Chambers J, Ciais P, Cook B, Davis KJ, Dolman AJ, Gielen B, Goulden M, Grace J, Granier A, Grelle A, Griffis T, GrÜnwald T, Guidolotti G, Hanson PJ, Harding R, Hollinger DY, Hutyra LR, Kolari P, Kruijt B, Kutsch W, Lagergren F, Laurila T, Law BE, Le Maire G, Lindroth A, Loustau D, Malhi Y, Mateus J, Migliavacca M, Misson L, Montagnani L, Moncrieff J, Moors E, Munger JW, Nikinmaa E, Ollinger SV, Pita G, Rebmann C, Roupsard O, Saigusa N, Sanz MJ, Seufert G, Sierra C, Smith M, Tang J, Valentini R, Vesala T, Janssens IA
(2007). $\mathrm{CO}_{2}$ balance of boreal, temperate, and tropical forests derived from a global database Global Change Biology 13 (12): 2509-2537. doi: 10.1111/j.1365-2486.2007.01439.x

Luyssaert S, Ciais P, Piao SL, Schulze ED, Jung M, Zaehle S, Schelhaas MJ, Reichstein M, Churkina G, Papale D, Abril G, Beer C, Grace J, Loustau D, Matteucci G, Magnani F, Nabuurs GJ, Verbeeck H, Sulkava M, van der Werf GR, Janssens IA (2010). The European carbon balance. Part 3: forests. Global Change Biology 16 (5): 1429-1450. - doi: 10.1111/j.1365-2486.200 9.02056.x

Malhi Y, Baldocchi DD, Jarvis PG (1999). The carbon balance of tropical, temperate and boreal forests. Plant, Cell and Environment 22: 715740. - doi: 10.1046/j.1365-3040.1999.00453.x Malhi Y, Aragào LE, Metcalfe DB, Paiva R, Quesada CA, Almeida S, Anderson L, Brando P, Chambers JQ, da Costa AC, Hutyra LR, Oliveira P, Patino S, Pyle EH, Robertson AL, Teixeira LM (2009). Comprehensive assessment of carbon productivity, allocation and storage in three Amazonian forests. Global Change Biology 15 (5): 1255-1274. - doi: 10.1111/j.1365-2486.200 8.01780.x

Manzoni S, Taylor P, Richter A, Porporato A, Agren GI (2012). Environmental and stoichiometric controls on microbial carbon-use efficiency in soils. New Phytologist 196: 79. - doi: 10.1111/j.1469-8137.2012.04225.x

Marland G, Garten Jr CT, Post WM, WestLuizao TO (2004). Studies on enhancing carbon sequestration in soils. Energy 29: 1643-1650. - doi: 10.1016/j.energy.2004.03.066

Marjanovic H, Alberti G, Balogh J, Czóbel Sz Horváth L, Jagodics A, Nagy Z, Ostrogovic MZ, Peressotti A, Führer E (2010). Measurements and estimations of biosphere-atmosphere exchange of greenhouse gases - Forests. In: "Atmospheric Greenhouse Gases: The Hungarian Perspective" (Haszpra L ed). Springer Science + Business Media, Berlin, Germany, pp. 121-156. Marjanovic H, Ostrogovic MZ, Alberti G, Balenovic I, Paladinic E, Indir K, Peressotti A, Vuletic D (2011). Carbon dynamics in younger stands of pedunculate oak during two vegetation periods. Sumarski List 135: 59-73.

Matson P, Johnson L, Billow C, Miller J, Pu RL (1994). Seasonal patterns and remote spectral estimation of canopy chemistry across the Oregon transect. Ecological Applications 4: 280-298. doi: 10.2307/1941934

Melillo JM, Aber JD, Muratore JF (1982). Nitrogen and lignin control of hardwood leaf litter decomposition dynamics. Ecology 63: 621-626. doi: $10.2307 / 1936780$

Mokany K, Raison RJ, Prokushkin AS (2006). Critical analysis of root: shoot ratios in terrestrial biomes. Global Change Biology 12: 84-96. - doi: 10.1111/j.1365-2486.2005.001043.x

Moorhead DL, Sinsabaugh RL (2006). A theoretical model of litter decay and microbial interaction. Ecological Monographs 76: 151-174. - doi: 10.1890/0012-9615(2006)076[0151:ATMOLD] 2.0.CO;2
Pan Y, Birdsey RA, Fang J, Houghton R, Kauppi PE, Kurz WA, Phillips OL, Shvidenko A, Lewis SL, Canadell JG, Ciais P, Jackson RB, Pacala SW, Mcguire AD, Piao S, Rautiainen A, Sitch S, Hayes D (2011). A large and persistent carbon sink in the world's forests. Science 333 (6045): 988-993. - doi: 10.1126/science. 1201609

Papale D, Reichstein M, Aubinet M, Canfora E, Bernhofer C, Kutsch W, Longdoz B, Rambal S, Valentini R, Vesala T, Yakir D (2006). Towards a standardized processing of Net Ecosystem Exchange measured with eddy covariance technique: algorithms and uncertainty estimation. Biogeosciences 3: 571-583. - doi: 10.5194/bg-3-57 1-2006

Parton WJ, Ojima DS, Schimel DS (1996). Models to evaluate soil organic matter storage and dynamics. In: "Structure and Organic Matter Storage in Agricultural Soils" (Carter R, Stewart BA eds). CRC Press, Boca Raton, FL, USA, pp. 420-448.

Persson T, Van Oene H, Harrison AF, Karlsson P, Bauer G, Cenry J, Couteaux MM, Dambrine E, Hogberg P, Kioller A, Mateucci G, Rudebeck A, Schulze ED, Paces T (2000). Experimental sites in the NYPHYS/CANIF project. In: "Carbon and nitrogen cycling in European forest ecosystems" (Schulze DE ed). Ecological Studies, 142, Springer Verlag, Heidelberg, Germany, pp. 14-48.

Phillips RP, Finzi AC, Bernhardt ES (2011). Enhanced root exudation induces microbial feedbacks to $\mathrm{N}$ cycling in a pine forest under longterm $\mathrm{CO}_{2}$ fumigation. Ecology Letters 14 (2): 187-194. - doi: 10.1111/j.1461-0248.2010.015 70.x

Phillips RP, Meier IC, Bernhardt ES, Grandy AS, Wickings K, Finzi AC (2012). Roots and fungi accelerate carbon and nitrogen cycling in forests exposed to elevated $\mathrm{CO}_{2}$. Ecology Letters 15: 1042-1049. - doi: 10.1111/j.1461-0248.2012.01 827.x

Post WM, Emanuel WR, Zinke PJ, Stangenberger AG (1982). Soil carbon pools and world life zone. Nature 298: 156-159. - doi: 10.1038/29815 $6 \mathrm{a} 0$

Quesada CA, Lloyd J, Schwarz M, Patiño S, Baker TR, Czimczik C, Fyllas NM, Martinelli L, Nardoto GB, Schmerler J, Santos AJ, Hodnett MG, Herrera R, Luizão FJ, Arneth A, Lloyd G, Dezzeo N, Hilke I, Kuhlmann I, Raessler M, Brand WA, Geilmann H, Moraes Filho JO, Carvalho FP, Araujo Filho RN, Chaves JE, Cruz Junior OF, Pimentel TP, Paiva R (2010). Variations in chemical and physical properties of Amazon forest soils in relation to their genesis. Biogeosciences 7 (5): 1515-1541. - doi: 10.5194/ bg-7-1515-2010

Raison RJ, Khanna PK, Connell MJ, Falkiner RA (1990). Effects of water availability and fertilization on $\mathrm{N}$ cycling in a stand of Pinus radiata. Forest Ecology and Management 30: 31-43. doi: 10.1016/0378-1127(90)90124-T

Raison RJ, Khanna PK, Benson ML, Myers BJ, McMurtrie RE, Lang ARG (1992). Dynamics of Pinus radiata foliage in relation to water and nitrogen stress: II. Needle loss and temporal 
changes in total foliage mass. Forest Ecology and Management 52: 159-178. - doi: 10.1016/03781127(92)90500-9

Ralston CW (1973). Annual primary productivity in a loblolly pine plantation. IUFRO biomass studies, College of Life Sciences and Agriculture, University of Maine, Orono, ME, USA, pp. 107-118.

Randerson JT, Chapin FS, Harden JW, Neff JC, Harmon ME (2002). Net ecosystem production: A comprehensive measure of net carbon accumulation by ecosystems. Ecological Applications 12: 937-947. - doi: 10.1890/1051-0761(2002)01 2[0937:NEPACM]2.0.CO;2

Rasse DP, Rumpel C, Dignac MF (2005). Is soil carbon mostly root carbon? Mechanisms for a specific stabilisation. Plant and Soil 269: 341356. - doi: 10.1007/s11104-004-0907-y

Rastetter EB, Agren GI, Shaver GR (1997). Responses of $\mathrm{N}$-limited ecosystems to increased $\mathrm{CO}_{2}$ : a balanced nutrition, coupled-element-cycles model. Ecological Applications 7: 444-460. - doi: 10.1890/1051-0761(1997)007[0444:RONLET]2.0.CO;2

Reichstein M, Falge E, Baldocchi D, Papale D, Aubinet M, Berbigier P, Bernhofer C, Buchmann N, Gilmanov T, Granier A, Grunwald T, Havrankova K, Ilvesniemi H, Janous D, Knohl A, Laurila T, Lohila A, Loustau D, Matteucci G, Meyers T, Miglietta F, Ourcival JM, Pumpanen J, Rambal S, Rotenberg E, Sanz M, Tenhunen 25 J, Seufert G, Vaccari F, Vesala T, Yakir D, Valentini R (2005). On the separation of net ecosystem exchange into assimilation and ecosystem respiration: review and improved algorithm. Global Change Biology 11: 1424-1439. - doi: 10.11 11/j.1365-2486.2005.001002.x

Reichstein M, Ciais P, Papale D, Valentini R, Running S, Viovy N, Cramer W, Granier A, Ogée J, Allard V, Aubinet M, Bernhofer C, Buchmann N, Carrara A, Grunwald T, Heimann M, Heinesch B, Knohl A, Kutsch W, Loustau D, Manca G, Matteucci G, Miglietta F, Ourcival J, Pilegaard K, Pumpanen J, Rambal S, Schaphoff S, Seufert G, Soussana JF, Sanz MJ, Vesala T, Zhao M (2007a). Reduction of ecosystem productivity and respiration during the European summer 2003 climate anomaly: a joint flux tower, remote sensing and modelling analysis Global Change Biology 13 (3): 634-651. - doi: 10.1111/j.1365-2486.2006.01224.x

Reichstein M, Papale D, Valentini R, Aubinet M, Bernhofer C, Knohl A, Laurila T, Lindroth A, Moors E, Pilegaard K, Seufert G (2007b). Determinants of terrestrial ecosystem carbon balance inferred from European eddy covariance flux sites. Geophysical Research Letters 34 (1): L01402-262. - doi: 10.1029/2006GL027880

Rey A, Pegoraro E, Tedesci V, De Parri I, Jarvis PG, Valentini R (2002). Annual variation in soil respiration and its components in a coppice oak forest in Central Italy. Global Change Biology 8: 851-866. - doi: 10.1046/j.1365-2486.2002.0052 1.X

Robinson TMP, La Pierre KJ, Vadeboncoeur MA, Byrne KM, Thomey ML, Colby SE (2012). Sea- sonal, not annual precipitation drives community productivity across ecosystems. Oikos 122 (5): 727-738. - doi: 10.1111/j.1600-0706.2012.206 55.x

Rustad LE, Campbell JL, Marion GM, Norby RJ, Mitchell MJ, Hartley AE, Cornelissen JHC, Gurevitch J (2001). A meta-analysis of the response of soil respiration, net nitrogen mineralization, and aboveground plant growth to experimental ecosystem warming. Oecologia 126: 543562. - doi: 10.1007/s004420000544

Ryan MG, Hubbard RM, Pongracic S, Raison RJ, McMurtrie RE (1996). Foliage, fine-root, woody-tissue and stand respirationin Pinus radiata in relation to nutrient status. Tree Physiology 16 : 333-343. - doi: 10.1093/treephys/16.3.333

Ryan MG, Lavigne MB, Gower ST (1997). Annual carbon cost of autotrophic respiration in boreal forest ecosystems in relation to species and climate. Journal of Geophysical Research 102: 28871-28883. - doi: 10.1029/97JD01236

Ryan MG, Binkley D, Fownes JH, Giardina CP, Senock RS (2004). An experimental test of the causes of forest growth decline with stand age. Ecological Monographs 74: 393-414. - doi: 10.1890/03-4037

Sanchez PA (1989). Soils. In: "Tropical Rain Forest Ecosystems: Biogeographical and Ecological Studies" (Lieth H, Werger MJA eds). Elsevier, New York, USA, pp. 132-161.

Scandellari F, Ventura M, Gioacchini P, Antisari LV, Tagliavini M (2010). Seasonal pattern of net nitrogen rhizodeposition from peach (Prunus persica (L.) Batsch) trees in soils with different textures. Agriculture Ecosystems and Environment 136: 162-168. - doi: 10.1016/j.agee.2009. 12.017

Scartazza A, Mata C, Mateucci G, Yakir D, Moscatello S, Brugnoli E (2004). Comparisons of $\delta^{13} \mathrm{C}$ of photosynthetic products and ecosystem respiratory $\mathrm{CO}_{2}$ and their resposnses to seasonal climate variability. Oecologia 140: 340351. - doi: 10.1007/s00442-004-1588-1

Schimel DS, House JI, Hibbard KA, Bousquet P, Ciais P, Peylin P, Braswell BH, Apps MJ, Baker D, Bondeau A, Canadell J, Churkina G, Cramer W, Denning AS, Field CB, Friedlingstein P, Goodale C, Heimann M, Houghton RA, Melillo JM, Moore B, Murdiyarso D, Noble I, Pacala SW, Prentice IC, Raupach MR, Rayner PJ, Scholes RJ, Steffen WL, Wirth C (2001). Recent patterns and mechanisms of carbon exchange by terrestrial ecosystems. Nature 414 (6860): 169172. - doi: 10.1038/35102500

Schimel JP, Schaeffer SM (2012). Microbial control over carbon cycling in soil. Frontiers in Microbiology, 3: 348.

Schrumpf M, Schulze ED, Kaiser K, Schumacher J (2011). How accurately can soil organic carbon stocks and stock changes be quantified by soil inventories? Biogeosciences 8: 1193-1212. - doi: 10.5194/bg-8-1193-2011

Six J, Frey SD, Thiet RK, Batten KM (2006). Bacterial and fungal contributions to carbon sequestration in agroecosystems. Soil Science Society of America Journal 70: 555-569. - doi: 10.2136/sssaj2004.0347

Sollins P, Homann P, Caldwell BA (1996). Stabilization and destabilization of soil organic matter: mechanisms and controls. Geoderma 74: 65105. - doi: 10.1016/S0016-7061(96)00036-5

Sotta ED, Meir P, Malhi Y, Nobre AD, Hodnett $\mathrm{M}$, Grace J (2004). Soil $\mathrm{CO}_{2}$ efflux in a tropical forest in the central Amazon. Global Change Biology 10: 601-617. - doi: 10.1111/j.1529-88 17.2003.00761.x

Stace HCT, Hubble GD, Brewer R, Northcote KH, Sleeman JR, Mulcahy MJ, Hallsworth EG (1968). A handbook of Australian soils. Rellim, Adelaide, Australia, pp. 435.

Steingrobe B, Schmid H, Claassen N (2000). The use of the ingrowth core method for measuring root production of arable crops - influence of soil conditions inside the ingrowth core on root growth. Journal of Plant Nutrition and Soil Science 163: 617-622. - doi: 10.1002/(ISSN)15222624

Subke JA, Inglima I, Cotrufo MF (2006). Trends and methodological impacts in soil $\mathrm{CO}_{2}$ efflux partitioning: A meta-analytical review. Global Change Biology 12: 921-943. - doi: 10.1111/j. 1365-2486.2006.01117.x

Sun OJ, Campbell J, Law BE, Wolf V (2004). Dynamics of carbon stocks in soils and detritus across chronosequences of different forest types in the Pacific Northwest, USA. Global Change Biology 10 (9): 1470-1481. - doi: 10.1111/j.13 65-2486.2004.00829.x

Tavares F, Fränzle O, Müller F, Schimmig C-G (2010). Long-term ecosystem research in a beech forest of northern Germany. In: "Long-Term Ecolgical Research: Between Theory and Application" (Müller F, Baessler C, Schubert H, Klotz $\mathrm{S}$ eds). Springer Science + Business Media BV, The Netherlands, pp. 253-261. - doi: 10.1007/ 978-90-481-8782-9 18

Tedeschi V, Rey A, Manca G, Valentini R, Jarvis PG, Borghetti M (2006). Soil respiration in a Mediterranean oak forest at different developmental stages after coppicing. Global Change Biology 12: 110-121. - doi: 10.1111/j.1365-24 86.2005.01081.x

Thomas RQ, Canham CD, Weathers KC, Goodale CL (2010). Increased tree carbon storage in response to nitrogen deposition in the US. Nature Geoscience 3 (1): 13-17. - doi: 10.1038/ngeo721 USDA Soil Conservation Service Soil Survey Staff (1975). Soil taxonomy: a basic system of soil classification for making and interpreting soil surveys. USDA Handbook 436, US Government Printing Office, Washington, DC, USA, pp. 754.

Valentini R, De Angelis P, Matteucci G, Monaco R, Dore S, Scarascia Mugnozza GE (1996). Seasonal net carbon dioxide exchange of a Beech forest with the atmosphere. Global Change Biology 2: 199-207. - doi: 10.1111/j.1365-2486.19 96.tb00072.x

Valentini R, Matteucci G, Dolman AJ, Schulze ED, Rebmann C, Moors EJ (2000). Respiration as the main determinant of carbon balance in $\mathrm{Eu}$ ropean forests. Nature 404: 861-865. - doi: 10.10 
38/35009084

Van Veen JA, Liljeroth E, Lekerkerk LJA, Van De Geijn SC (1991). Carbon fluxes in plant-soil systems at elevated atmospheric $\mathrm{CO}_{2}$ levels. Ecological Applications 1: 175-181. - doi: 10.2307/19 41810

Vicca S, Janssens IA, Wong SC, Cernusak LA, Farquhar GD (2010). Zea mays rhizosphere respiration, but not soil organic matter decomposition was stable across a temperature gradient. Soil Biology and Biochemistry 42: 2030-2033. doi: 10.1016/j.soilbio.2010.07.023

Vicca S, Luyssaert S, Peñuelas J, Campioli M, Chapin FS, Ciais P, Heinemeyer A, Högberg P, Kutsch WL, Law BE, Malhi Y, Papale D, Piao SL, Reichstein M, Schulze ED, Janssens IA (2012). Fertile forests produce biomass more efficiently. Ecology Letters 15 (6): 520-526. - doi: 10.1111/j.1461-0248.2012.01775.x

Vogel CS, Curtis PS, Thomas RB (1997). Growth and nitrogen accretion of dinitrogen-fixing Alnus glutinosa (L) Gaertn under elevated carbon dio- xide. Plant Ecology 130: 63-70. - doi: 10.1023/ A:1009783625188

Wardle DA, Bardgett RD, Klironomos JN, Setala H, Van Der Putten WH, Wall DH (2004). Ecological linkages between aboveground and belowground biota. Science 304: 1629-1633. - doi: $10.1126 /$ science. 1094875

Woodwell GM, Botkin DB (1970). Metabolism of terrestrial ecosystems by gas exchange techniques: the Vrookhaven approach. In: "Analysis of temperate forest ecosystems" (Reichle DE eds). Springer-Verlag, New York, USA, pp. 7385.

Yang Y, Luo Y (2011). Carbon: nitrogen stoichiometry in forest ecosystems during stand development. Global ecology and Biogeography 20: 354-361. - doi: 10.1111/j.1466-8238.2010.0060 2.X

Yin H, Yufei L, Xiao J, Xu Z, Cheng X, Liu Q (2013). Enhanced root exudation stimulates soil nitrogen transformations in a subalpine coniferous forest under experimental warming. Global
Change Biology 19 (7): 2158-2167. - doi: 10.111 1/gcb. 12161

Zha TS, Barr AG, Bernier PY, Lavigne MB, Trofymow JA, Amiro BD, Arain MA, Bhatti JS, Black TA, Margolis HA, McCaughey JH, Xing ZS, Van Rees KCJ, Coursolle C (2013). Gross and aboveground net primary production at Canadian forest carbon flux sites. Agricultural and Forest Meteorology 174-175: 54-64. - doi: 10.1016/j.agrformet.2013.02.004

\section{Supplementary Material}

\section{Appendix 1}

Box S1 - Nutrient classification.

Tab. S1 - Spearman correlation matrix for the six Mediterranean forests considered in the study.

Link: Alberti_1196@supp1001.pdf 